\title{
Dissolution Kinetics of Alumina Calcine
}

T. A. Batcheller

T. G. Garn

D. R. Peterman

September 2001

Idaho National Engineering and Environmental Laboratory Bechtel BWXT Idaho, LLC 
INEEL/EXT-01-01225

\title{
Dissolution Kinetics of Alumina Calcine
}

\author{
T. A. Batcheller \\ T. G. Garn \\ D. R. Peterman
}

September 2001

Idaho National Engineering and Environmental Laboratory Idaho Falls, Idaho 83415

\author{
Prepared for the \\ U.S. Department of Energy \\ Assistant Secretary for Environmental Management \\ Under DOE Idaho Operations Office \\ Contract DE-AC07-99ID13727
}




\section{SUMMARY}

Dissolution kinetics of alumina type non-radioactive calcine was investigated as part of ongoing research that addresses permanent disposal of Idaho High Level Waste (HLW). Calcine waste was produced from the processing of nuclear fuel at the Idaho Nuclear Technology and Engineering Center (INTEC). Acidic radioactive raffinates were solidified at $\sim 500^{\circ} \mathrm{C}$ in a fluidized bed reactor to form the dry granular calcine material. Several Waste Management alternatives for the calcine are presented in the Idaho High Level Waste Draft EIS. The Separations Alternative addresses the processing of the calcine so that the HLW is ready for removal to a national geological repository by the year 2035. Calcine dissolution is the key front-end unit operation for the separations alternative.

Because aluminum and zirconium-type fuels were predominately reprocessed at the INTEC, alumina and zirconia-type calcines were produced and stored. Dissolution kinetics testing with non-radioactive pilot plant zirconia calcine has been previously investigated. Similar to that work, the scope of this present alumina calcine dissolution work included: 1) chemical and physical analyses of the calcine material, 2) baseline dissolution testing to determine: order of reaction, activation energy (Arrhenius analysis), and dissolution rate controlling mechanism (chemical reaction or mass transfer limited). Testing was also performed to determine if complete dissolution is equilibrium/solubility inhibited.

Chemical and physical analyses were performed on the RSH-1 alumina type pilot plant calcine bed material. Elemental fusion analysis results agree well with microprobe analysis results. An average value of the calcine acid consumption coefficient, $\mathbf{b}$, was determined for RSH-1 bed product material; $\mathbf{b}=19.8$ grams RSH-1 dissolved per mol of acid consumed. The order of reaction testing revealed that, just as in the case for the Run 74 zirconia pilot plant calcine testing, the homogeneous rate form fit the rate data better than the heterogeneous rate form. A characteristic dissolution fractal dimension, $\mathrm{D}_{\mathrm{R}}$, was determined for alumina and zirconia pilot plant calcine milled material and bed particles. The result from this fractal treatment of the dissolution data further supports the indication that calcine dissolution is more dependent upon its physical characteristics, rather than its chemical characteristics. Arrhenius testing yielded an apparent activation energy $\left(\mathrm{E}_{\mathrm{A}}\right)$ of $26.9 \mathrm{kcal} / \mathrm{mol}$ for RSH-1 alumina pilot plant calcine under conditions of constant $6 \underline{\mathrm{M}}$ acid concentration. The dissolution rate controlling mechanism testing results were inconclusive. Nevertheless, it was noted that, just as with all previous calcine dissolution testing, this testing with RSH-1 showed the familiar initial rapid dissolution then the leveling-out of the rate, and the non-attainment of $100 \%$ dissolution after long dissolution times - it too had the characteristics of internal mass diffusion controlled dissolution. The equilibrium/solubility inhibition testing results indicated that, the slowing dissolution rate of alumina compounds was preventing complete dissolution, and the data did not suggest that complete dissolution of RSH-1 calcine was equilibrium/solubility inhibited. The greatest percent mass dissolution observed during this testing with RSH-1 was $93.0 \%$; this was achieved after eight hours of dissolution at $95^{\circ} \mathrm{C}$. 


\section{ACKNOWLEDGEMENTS}

The authors wish to take this opportunity to thank Mr. Arlin Olson and Dr. R. Scott Herbst for their expert review and input. Thanks to Messrs. Mike Phippen and Wade Waddoups (machine shop), and Gary Gregston (glass shop) for providing special laboratory equipment fabrication services. Thanks to Mr. Wes Gamett for his invaluable help with the laboratory work. Thanks to Ms. Karen Wright for her microprobe analysis work. And finally, thanks to the INTEC analytical department for their accurate and expeditious sample result reporting. Without the work ethic and dedication of these employees, this work would never have been accomplished. 


\section{CONTENTS}

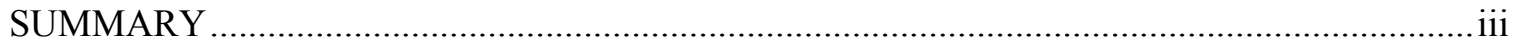

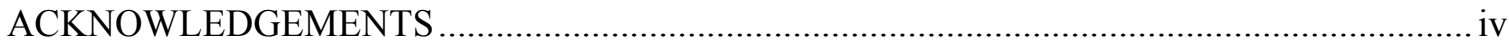

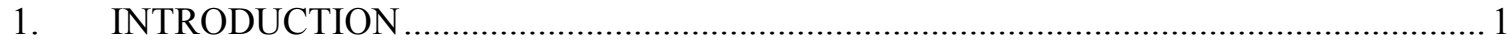

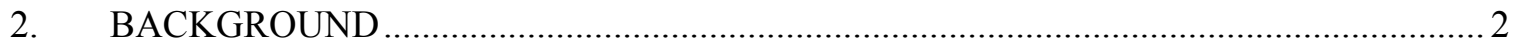

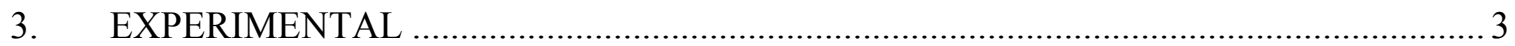

3.1 Chemical and Physical Analyses of RSH-1 Alumina Calcine …............................... 3

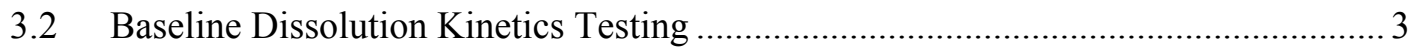

3.2.1 Calcine Consumption Coefficient Testing ............................................ 3

3.2.2 Order of Reaction Testing............................................................. 4

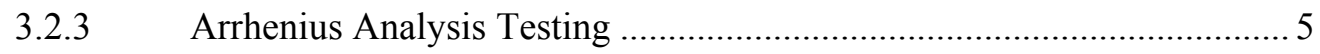

3.2.4 Dissolution Rate Controlling Mechanism Testing ................................ 5

3.2.5 Equilibrium/Solubility Inhibition Testing ......................................... 5

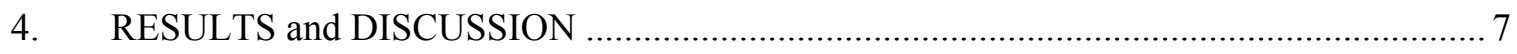

4.1 Chemical and Physical Analyses of RSH-1 Alumina Calcine Results ..................... 7

4.1.1 Estimate RSH-1 Calcine Compounds ............................................. 10

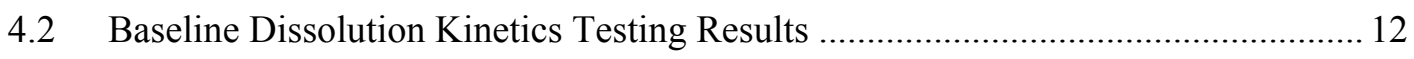

4.2.1 Calcine Consumption Coefficient Testing ........................................ 12

4.2.2 Order of Reaction Testing Results ................................................... 12

4.2.3 Arrhenius Analysis Testing Results.................................................... 15

4.2.4 Dissolution Rate Controlling Mechanism Testing Results ..................... 16

4.2.5 Equilibrium/Solubility Inhibition Testing Results ............................. 17

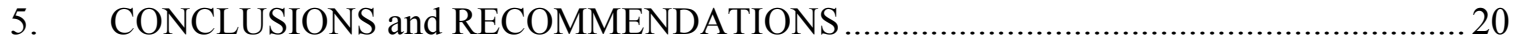

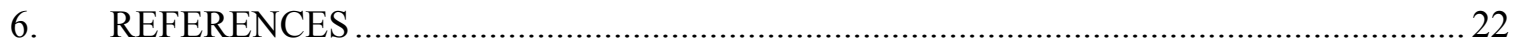

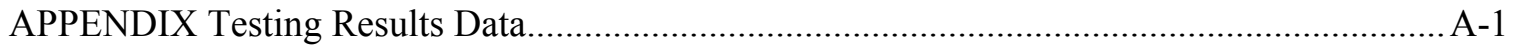




\section{FIGURES}

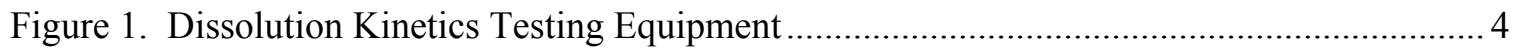

Figure 2. Electron microprobe analysis results; 250 to $300 \mu \mathrm{m} \mathrm{RSH-1}$ bed particles................... 8

Figure 3. SEM photomicrographs of RSH-1 bed particles ....................................................

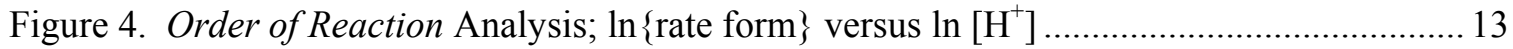

Figure 5. Fractal dimension interpretation of calcine dissolution............................................ 15

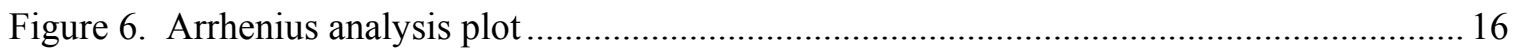

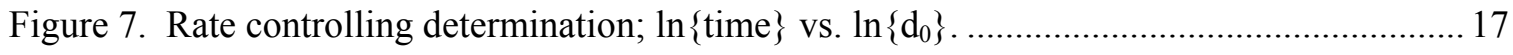

Figure 8. RSH-1 Component Conversion vs. Time; $6 \underline{\mathrm{M}} 75^{\circ} \mathrm{C}$ data.......................................... 18

Figure 9. Electron microprobe results for $475 \mu \mathrm{m}$ RSH-1 bed particles................................... A-2

Figure 10. Microprobe analysis of RSH-1 fines particle ...................................................

Figure 11. $3^{\text {rd }}$ order non-uniform rational B-spline curvefit ............................................... A-8

\section{TABLES}

Table 1. Order of Reaction Testing Parameters ........................................................................ 4

Table 2. Dissolution Rate Controlling Testing Screened Material Sizes ...................................... 5

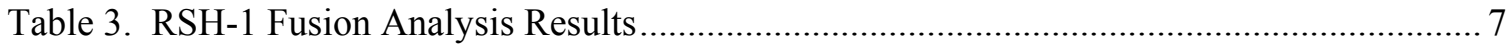

Table 4. Compare Bed Particle Fusion versus Microprobe Analyte Results Data. ....................... 8

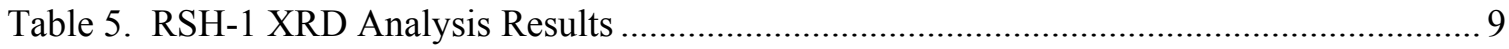

Table 6. Estimate of Calcine Compounds in RSH-1; HSC Equilibrium Calculations. ................ 10

Table 7. Compare HSC Estimated Element wt\% Against Fusion/Microprobe Results................ 11

Table 8. RSH-1 Calcine Acid Consumption Coefficient Testing Results. .................................. 12

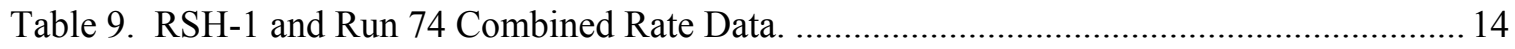

Table 10. Comparison of Mass Conversion; Experimental vs. Back-Calculated........................ 19

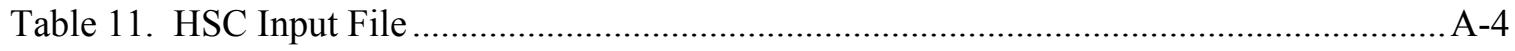

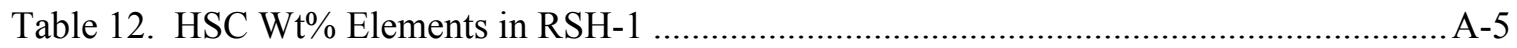




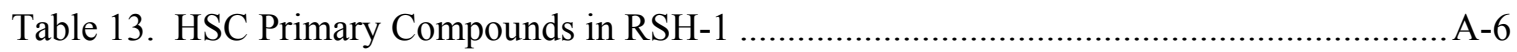

Table 14. Order of Reaction Testing Data..............................................................................

Table 15. Order of Reaction Initial Rate Curve Fit Results and Rate Forms.............................A-8

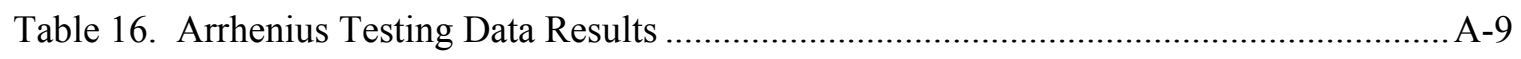

Table 17. Arrhenius Testing Data Curve-fit Results............................................................. A-9

Table 18. Dissolution Rate Controlling Testing Data........................................................ A-10

Table 19. Dissolution Rate Controlling Mechanism Data Curve-fit Results........................... A-11

Table 20. Equilibrium/Solubility Inhibition Testing Liquid Phase Analytical Results. ........... A-12

Table 21. Equilibrium/Solubility Inhibition Testing Elemental Conversion Results. .............. A-13

Table 22. Equilibrium/Solubility Inhibition Testing Elemental Conversion Results (cont.)....A-14 


\section{Dissolution Kinetics of Alumina Calcine \\ 1. INTRODUCTION}

Nuclear fuels were reprocessed at the Idaho Nuclear Technology Engineering Center (INTEC) (formerly the Idaho Chemical Processing Plant) located at the Idaho National Engineering and Environmental Laboratory (INEEL) for about 35 years. These were predominately aluminum and zirconium type fuels. They were dissolved in acidic aqueous media and the uranium was separated from the radioactive solutions utilizing liquid-liquid extraction processes. The liquid radioactive raffinates were subsequently solidified (calcined) in a fluidized bed reactor to form a dry granular material. Originally calcination was accomplished with an in-bed heat exchanger at $400^{\circ} \mathrm{C}$ and subsequently (beginning in 1970 ) at $500^{\circ} \mathrm{C}$ with in-bed combustion of kerosene. This calcine has been provisionally stored near surface in concrete encased stainless steel bins at the INTEC. The radioactive nuclides constitute only about one weight percent of the calcine; the remainder is non-radioactive fuel matrix and fuel reprocessing material.

Research addressing the permanent immobilization of radioactive waste has been ongoing. Several Waste Management alternatives are presented in the Idaho High Level Waste (HLW) Draft EIS ${ }^{1}$. The Separations Alternative addresses the processing of the calcine so that it is ready for shipment to a national geological repository by the year 2035. Separations reduces the HLW radioactive waste volume to be ultimately stored at the repository. Nitric acid dissolution of the calcine is an essential front-end unit operation in the separations option. In order to design calcine dissolution equipment, a dissolution reaction rate expression is required. Investigation of the dissolution kinetics of an alumina type calcine is presented in this report. 


\section{BACKGROUND}

Pilot plant scale fluidized bed calciners have been utilized since the early 1960's to develop and verify calcination flowsheets for the various radioactive liquid wastes generated at the INTEC. A non-radioactive calcine material is produced in these pilot plant calciners and it is physically and chemically similar to the actual radioactive calcine. Typically, dissolution of the pilot plant calcine is part of the scope of calcination development work. In addition, dissolution studies were performed to support the ongoing operations at the INTEC radioactive waste calcination facilities ${ }^{2,3}$. These studies have traditionally been qualitative in nature, most resulting in a "snapshot" of the dissolution (usually after an hour of dissolution time), and a dissolution rate expression for a calcine dissolver design was not addressed. The dissolution kinetics and dynamics of a zirconia-type pilot plant calcine (designated as Run74) was previously investigated ${ }^{4}$. This work primarily used mass conversion and coupled in-dissolution particle size distribution (psd) data to develop an expression for the rate of dissolution. This dissolution model was fairly constrained. The data indicated that calcine dissolution was controlled by pore diffusion inside the particle.

During his work with calcine, Herbst realized an adequately representative alumina pilot plant calcine was not available 5 . Of primary concern was a representative boron and mercury content. Mercury was used as a catalyst during dissolution of aluminum-clad fuel, and boron was added to enhance formation of the more soluble amorphous phase alumina during the calcination process. Based on this, the Applied Technology 10-cm pilot plant calciner was utilized to produce a representative alumina calcine surrogate. Approximately $30 \mathrm{lbs}$. of alumina type calcine was produced in December of 1998, and was designated as "RSH-1". The study of the dissolution kinetics of this calcine is presented in this report.

The scope of the dissolution kinetics testing performed with the RSH-1 alumina pilot plant calcine included: 1) chemical and physical analyses, 2) baseline dissolution testing to determine: order of reaction, activation energy (Arrhenius analysis), and dissolution rate controlling mechanism (chemical reaction or mass transfer limited). Testing was also performed to determine if complete dissolution is equilibrium/solubility inhibited. 


\section{EXPERIMENTAL}

\subsection{Chemical and Physical Analyses of RSH-1 Alumina Calcine}

To determine the chemical composition of RSH-1 calcine material, three types of fusion analysis were performed - lithium tetraborate, sodium hydroxide, and sodium carbonate. These fusion methods are utilized for determining a target set of analytes. Most metals are determined with the lithium tetraborate fusion. Nitrate, chloride, sulfate, and lithium and boron are determined via the sodium hydroxide fusion. The sodium carbonate fusion is used to determine the fluoride and phosphate composition. Fusion analyses were performed on both bed product and the fines material. There were no special sample preparations used prior to the analysis.

Oxygen content in calcine is significant. Since oxygen can not be determined using the fusion analysis methods, an electron microscope was used to obtain wt. \% oxygen in RSH-1; several other light elements were also analyzed. A JEOL JXA-8900R Electron Microprobe instrument was utilized for this purpose. Bed product particles were mounted in a small epoxy disk cast. This disk was ground and polished. By this technique, full particle cross sections are available for analysis. Analyses were done for near exterior particle surface locations, and for locations near the center of the particle. Mount preparations were typical; carbon coated mounts were used for all analytes except carbon; aluminum coated mounts were used for determining carbon. In addition to these microprobe analyses, a Scanning Electron Microscope (SEM) was used to obtain photomicrographs, providing some morphological information about this alumina calcine. An R.J. Lee Personal SEM was used. In addition, X-ray diffraction analyses were performed using a Siemans D-5000 X-Ray Diffractometer/Generator.

\subsection{Baseline Dissolution Kinetics Testing}

\subsubsection{Calcine Consumption Coefficient Testing}

Testing was performed to determine the acid consumption coefficient (b) for RSH-1 alumina type pilot plant calcine. This testing was performed with 2 grams of calcine per 100 $\mathrm{mLs}$ of acid, at both 60 and $>95^{\circ} \mathrm{C}$, and with either $4 \underline{\mathrm{M}}$ or $6 \underline{\mathrm{M}}$ nitric acid. Tests were performed for a minimum of 1 hour, and up to 7 hours of dissolution time. Testing equipment and methods used for determining $\mathbf{b}$ were the same as those used in the zirconia calcine kinetics testing ${ }^{4}$. 


\subsubsection{Order of Reaction Testing}

Order of reaction testing on RSH-1 was performed to classify the dissolution reaction (homogeneous or heterogeneous) and to determine the order of the dissolution reaction with respect to the acid concentration. This testing was performed with screened bed particle material. This was done to obtain as narrow a particle size material as possible; the average particle size used in this testing was $462 \mu \mathrm{m}$. Dissolutions were performed at $75^{\circ} \mathrm{C}$ under conditions of unchanging acid concentration. The ratio of test calcine mass to volume of acid to accomplish this was calculated using the consumption coefficient b. For each acid molarity, tests were performed for $1,2,3,6$, and 12 minutes of dissolution time. These data were curvefit to determine the initial rate of dissolution $($ at time $=$ zero). The dissolver vessel equipment used in this testing is shown in Figure 1.

The calcine was added to the at-temperature acid volume in the dissolver vessel. At the predetermined dissolution time, the dissolving slurry was quickly removed and filtered through a pre-weighed Nalgene $0.45 \mu \mathrm{m}$ cellulose nitrate membrane disposable filter. A filtered liquid sample was obtained and

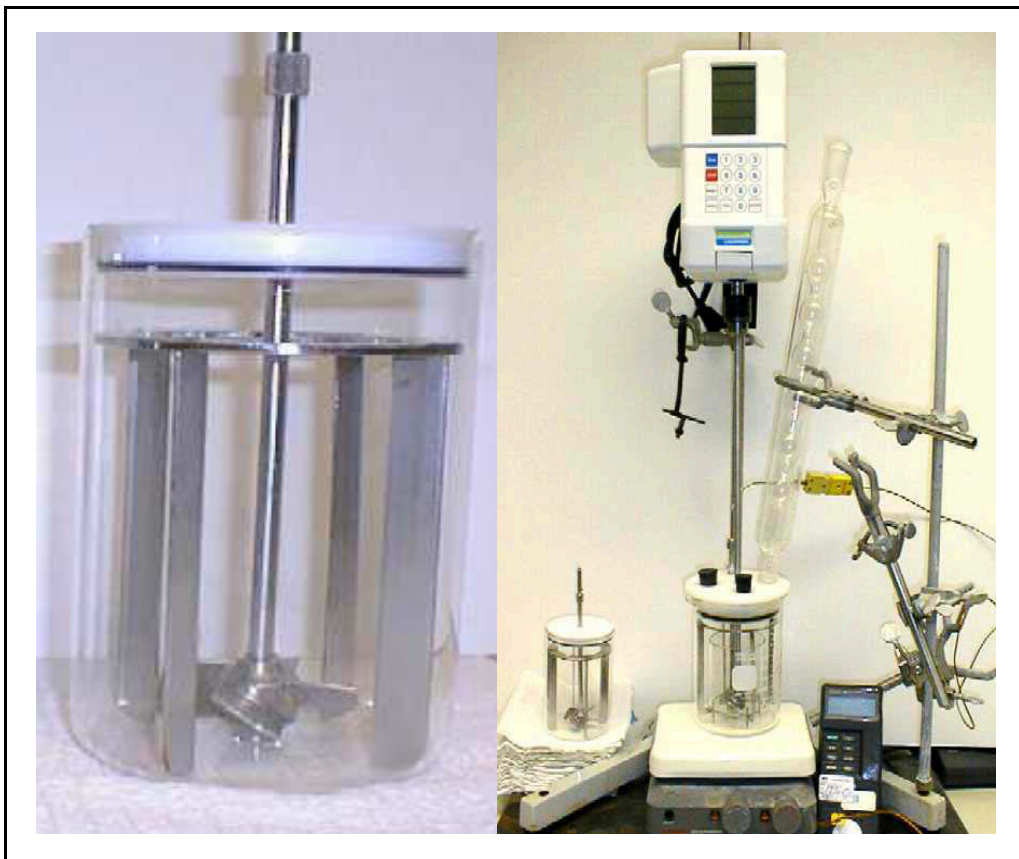

Figure 1. Dissolution Kinetics Testing Equipment submitted for chemical analysis. The UDS were thoroughly water washed and then dried in a convective oven at $50^{\circ} \mathrm{C}$ for 6 hours or longer (overnight). Percent mass dissolution (or mass conversion) was determined from the dried mass remaining on the filter. The experimental parameters used in the order of reaction testing are presented in Table 1.

Table 1. Order of Reaction Testing Parameters

\begin{tabular}{|c|c|c|c|c|c|}
\hline $\begin{array}{c}\text { Acid } \\
\underline{M}\end{array}$ & 0.5 & 1.0 & 3.0 & 6.0 & 8.0 \\
\hline $\begin{array}{c}\text { Avg. Initial Calcine Mass } \\
\text { (grams) }\end{array}$ & 0.4154 & 0.4481 & 1.201 & 2.192 & 1.243 \\
\hline $\begin{array}{c}\text { Acid Volume } \\
\text { (mLs) }\end{array}$ & 1000 & 500 & 400 & 400 & 400 \\
\hline
\end{tabular}




\subsubsection{Arrhenius Analysis Testing}

Arrhenius analysis testing was performed to determine the activation energy for dissolution of RSH-1. Testing was performed under the following conditions: 2.2 grams of starting calcine mass in $400 \mathrm{mLs}$ of well-agitated $6 \underline{\mathrm{M}}$ nitric acid (unchanging concentration during dissolution) - and dissolved for 1, 2, 3, 6, and 12 minutes. Again, these data were used to determine the initial rate of dissolution. This testing was performed using material with an average particle size of $475 \mu \mathrm{m}$. This testing was executed in the same manner described above in the order of reaction testing segment - the material was added to the at-temperature acid and then the vessel was removed at the predetermined time and filtered; mass conversion as a function of time was determined from dried filter mass and liquid samples were retrieved and submitted for analysis. This Arrhenius test matrix was performed at dissolution temperatures of $60,67.5,75,85$, and $95^{\circ} \mathrm{C}$. A Cole Parmer Polystat Constant Temperature Circulator automatic temperature bath was used to maintain test temperature. This temperature bath setup was used for all baseline kinetics testing.

\subsubsection{Dissolution Rate Controlling Mechanism Testing}

Testing was performed to determine the dissolution rate controlling mechanism. A temperature of $75^{\circ} \mathrm{C}$ was used throughout this testing. $\mathrm{RSH}-1$ bed material was screened to obtain as narrow a particle size material as possible (except for the material used in the Arrhenius testing). For smaller particle sizes, the bed material required grinding in a jar mill. The various size ranges of this material is provided in Table 2 .

Table 2. Dissolution Rate Controlling Testing Screened Material Sizes

\begin{tabular}{|c|c|c|c|}
\hline U.S. Standard Size & $\begin{array}{l}\text { Particle Size Range } \\
(\mu \mathrm{m})\end{array}$ & $\begin{array}{l}\text { Avg. Particle Size } \\
(\mu \mathrm{m})\end{array}$ & \\
\hline $120-100$ & $125 \gg 150$ & 137 & \multirow{2}{*}{ 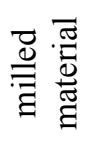 } \\
\hline $60-50$ & $250 \gg 300$ & 257 & \\
\hline $45-30 \dagger$ & $355 \gg 595$ & 475 & \multirow{3}{*}{ 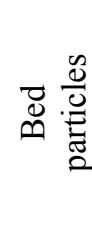 } \\
\hline $30-25$ & $595 \gg 710$ & 655 & \\
\hline $20-18$ & $850 \gg 1000$ & 925 & \\
\hline
\end{tabular}

For each narrow particle size range, the mass was uniformly split into predetermined per-dissolution aliquots using a spinning riffler. This same riffling technique was employed for all of the other baseline dissolution kinetics testing described earlier. Mass dissolution was again determined as a function of time. At each given average particle size, dissolutions were performed for 2, 6, 12, 30, and 60 minutes: with an additional test for 7 to 8 hours.

\subsubsection{Equilibrium/Solubility Inhibition Testing}

Additional tests were performed to determine if complete dissolution is equilibrium/solubility inhibited. These tests were performed with the Arrhenius test conditions 
and material, except dissolutions were carried out for 1 to 8 hours. Tests were performed at 75 and $95^{\circ} \mathrm{C}$, and the liquid sample data for these longer time tests were combined with the shorter time test data (the $1,2,3,6$, and 12 minute 75 and $95^{\circ} \mathrm{C}$ data). The same approximately narrow size range bed material (near $475 \mu \mathrm{m}$ ) was used to maintain a consistency between this equilibrium/solubility inhibition testing, the Arrhenius, and the order of reaction testing. 


\section{RESULTS AND DISCUSSION}

\subsection{Chemical and Physical Analyses of RSH-1 Alumina Calcine Results}

Analytical Laboratory results for the fusion analyses performed on the RSH-1 bed product and fines are presented in Table 3.

Table 3. RSH-1 Fusion Analysis Results

\begin{tabular}{|c|c|c|c|}
\hline \multicolumn{2}{|c|}{ RSH-1 Product Composition } & \multicolumn{2}{|c|}{ RSH-1 Fines Composition } \\
\hline $\begin{array}{l}\text { Log \# } \\
010102-9\end{array}$ & & $\begin{array}{l}\log \# \\
010226-4\end{array}$ & \\
\hline Analyte & Result (wt\%) & Analyte & Result (wt \%) \\
\hline \multicolumn{2}{|c|}{ Metals } & \multicolumn{2}{|c|}{ Metals } \\
\hline Aluminum & $4.55451 \mathrm{E}+01$ & Aluminum & $2.44734 \mathrm{E}+01$ \\
\hline Boron & 3.17442E-01 & Boron & 2.37074E-01 \\
\hline Calcium & 3.46267E-01 & Calcium & 1.62283E-01 \\
\hline Cesium & 1.67E-02 & Cesium & 1.14E+00 \\
\hline Europium & $2.63295 \mathrm{E}-02$ & Europium & 2.75377E-03 \\
\hline Iron & 3.73314E-02 & Iron & 5.94434E-02 \\
\hline Magnesium & 1.98911E-01 & Magnesium & $2.12800 \mathrm{E}-01$ \\
\hline Mercury & 4.46E-01 & Mercury & 7.88E-01 \\
\hline Silicon & 2.60212E-02 & Silicon & 4.61494E-02 \\
\hline Sodium & 1.94E+00 & Sodium & $2.42 \mathrm{E}+00$ \\
\hline Strontium & $9.75915 \mathrm{E}-03$ & Strontium & $2.27898 \mathrm{E}-03$ \\
\hline \multicolumn{2}{|c|}{ Anions } & \multicolumn{2}{|c|}{ Anions } \\
\hline Analyte & Result (mg/g) & Analyte & Result (mg/g) \\
\hline Chloride & $4.3713 \mathrm{E}-01$ & Chloride & $2.7379 E+00$ \\
\hline Nitrate & $6.44422 \mathrm{E}+01$ & Nitrate & $8.3974 \mathrm{E}+01$ \\
\hline
\end{tabular}

For these fusion results, there was a notable wt $\%$ difference between the bed product and fines results for aluminum, cesium and chloride. The bed product total $\mathrm{wt} \%$ was approximately $17 \mathrm{wt} \%$ more than the fines, with the greatest difference attributed to aluminum.

Microprobe results for the RSH-1 bed particles of average diameter size $275 \mu \mathrm{m}$ are presented in Figure 2. Microprobe results for the $\sim 475 \mu \mathrm{m}$ size bed material, and RSH-1 fines material are presented in Figure 9 and Figure 10 in the Appendix. A comparison between the bed particle fusion data versus the microprobe analysis data (for some selected analytes) is presented in Table 4. A significant discrepancy was noted between the fusion and microprobe results for aluminum $-24.5 \mathrm{wt} \%$ versus $41.9 \mathrm{wt} \%$ respectively (see Appendix, Figure 10).

Triplicate fusion analysis for both the product and the fines was desired, and would provide better information regarding this potential compositional differences between the RSH-1 product and fines (as indicated by these initial fusion results); (it could also resolve the aluminum discrepancy between the fusion and microprobe results noted with the fines). Future work should address this issue. 


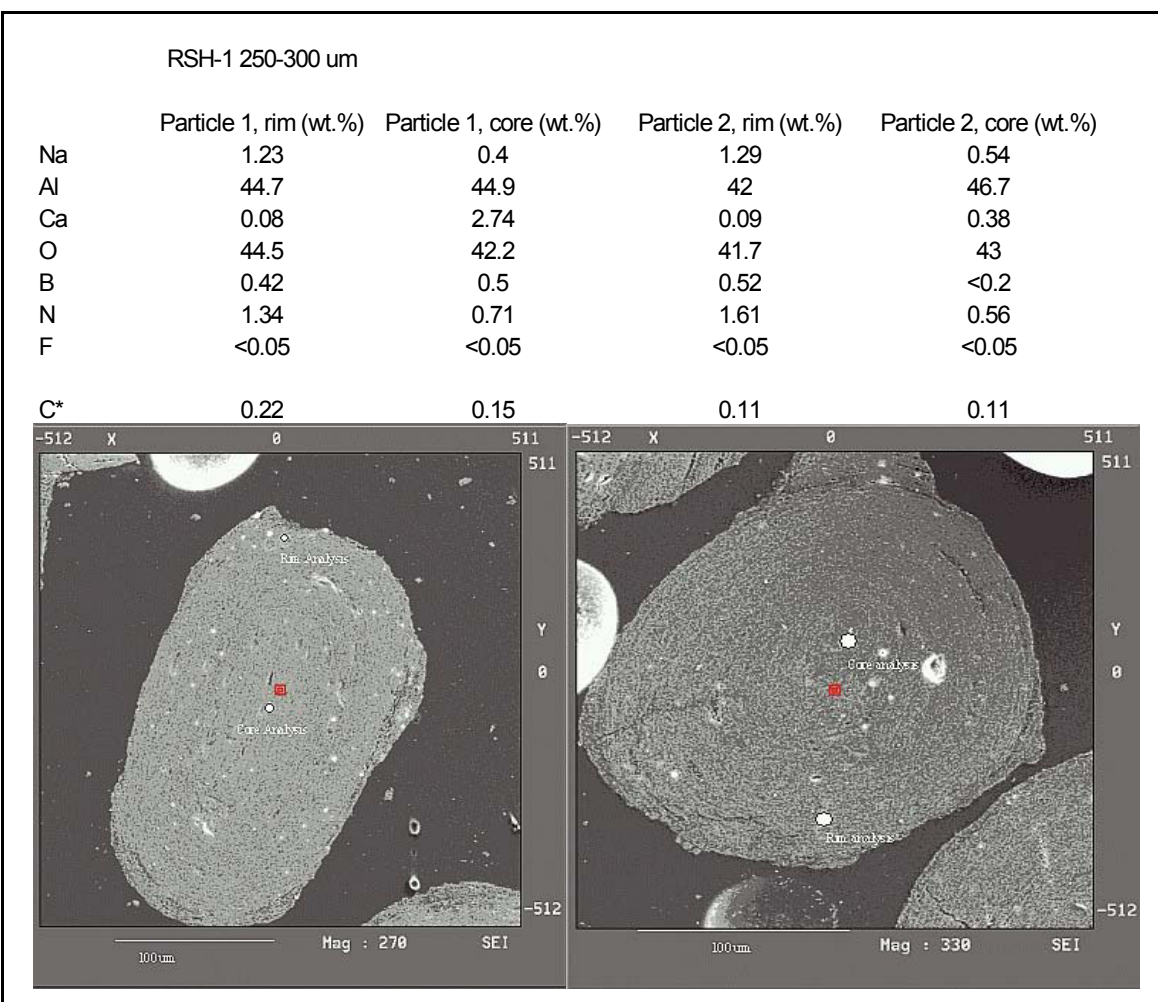

Figure 2. Electron microprobe analysis results; 250 to $300 \mu \mathrm{m} \mathrm{RSH}-1$ bed particles.

Table 4. Compare Bed Particle Fusion versus Microprobe Analyte Results Data.

\begin{tabular}{|c|c|c|c|c|c|c|}
\hline Method & \multicolumn{6}{|c|}{ Analyte } \\
\hline $\begin{array}{c}\text { Fusion } \\
\text { wt\% }\end{array}$ & 45.54 & 1.94 & 0.35 & 0.32 & - & - \\
\hline $\begin{array}{c}\text { Microprobe } \\
\text { avg. wt \% }\end{array}$ & 44.1 & 0.92 & 0.50 & 0.52 & 42.48 & 0.12 \\
\hline
\end{tabular}

Considering this limited data, the agreement between the bed particle fusion and microprobe results is reasonable. As alluded to earlier, triplicate fusion analysis and additional microprobe analyses were desired, but because of limited resources, were not requested. Triplicate analyses are recommended if better accuracy is necessary.

SEM photomicrographs were obtained for RSH-1 bed particle material (see Figure 3). A bed particle was fractured to obtain a view of a particle's interior; the highly porous and non-structured nature of the RSH-1 calcine was observed. A summary of RSH-1 bed material and fines XRD results is presented in Table 5. 
Table 5. RSH-1 XRD Analysis Results

\begin{tabular}{|l|l|l|}
\hline Sample Name & Results & Log\#9902236 \\
\hline RSH-1 Product & $\begin{array}{l}\text { This sample is mostly amorphous. } \mathrm{Al}_{2} \mathrm{O}_{3} \text { (Corundum) } \\
\text { and } \mathrm{Al}_{2} \mathrm{O}_{3} \text { (gamma-Alumina) are present as minor } \\
\text { components. }\end{array}$ \\
\hline RSH-1 Fines & $\begin{array}{l}\mathrm{NaNO}_{3} \text { (nitratine) and also } \mathrm{Al}_{2} \mathrm{O}_{3} \text { (Corundum) are the } \\
\text { major crystalline components of this sample. }\end{array}$ \\
\hline
\end{tabular}

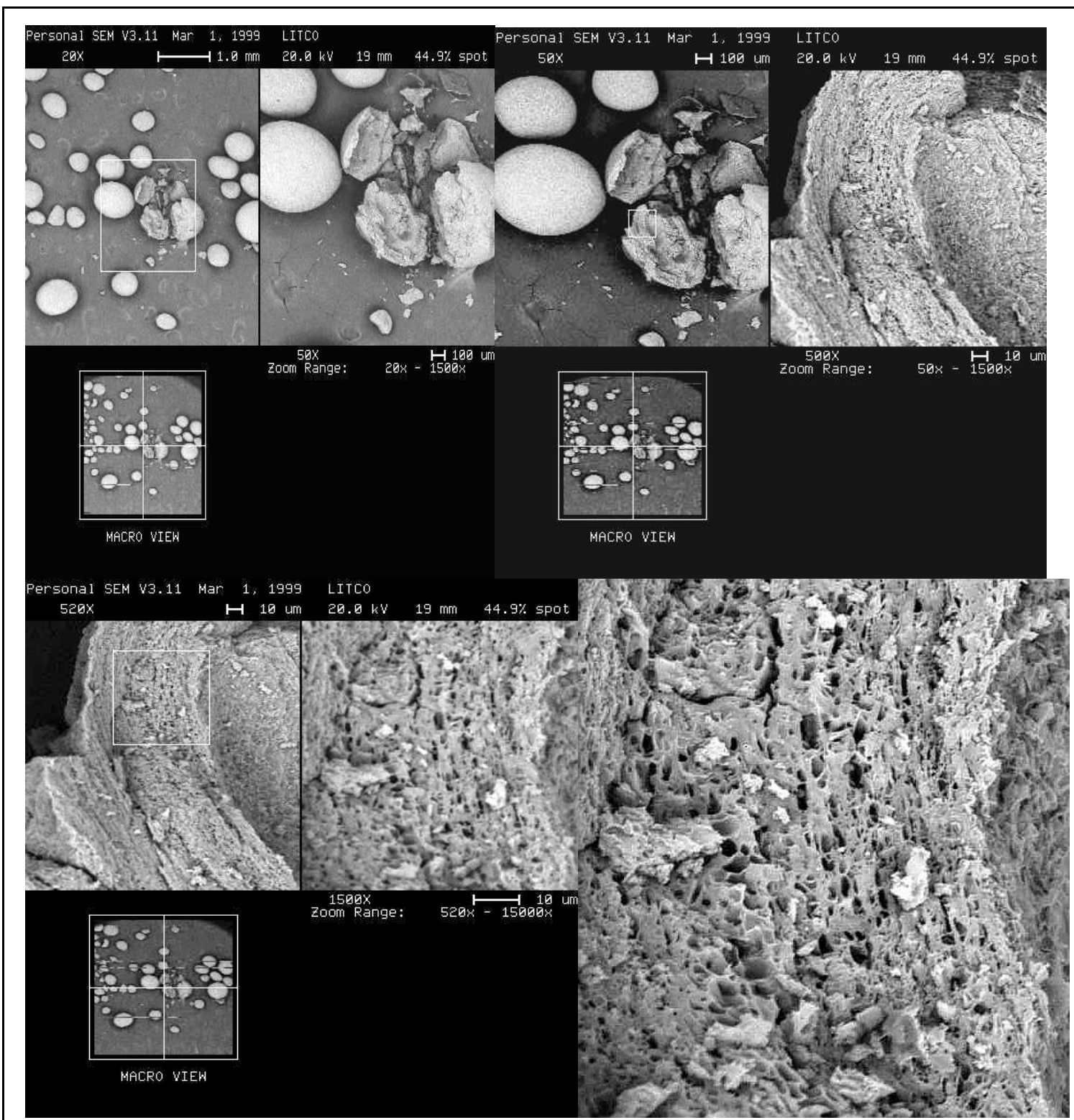

Figure 3. SEM photomicrographs of RSH-1 bed particles 


\subsubsection{Estimate RSH-1 Calcine Compounds}

Similar to the work done by Brewer and Kessinger ${ }^{6}$, a thermodynamic equilibrium program - HSC Chemistry ${ }^{\circledR}$ for Windows ${ }^{7}$ — was utilized to estimate chemical compounds formed in RSH-1 during the calcination process. A species list was generated with this software from the elements in the RSH-1 flowsheet feed. Condensed solid phase species (calcine products) were also included in this species list. An equilibrium module input file was created from this list. The RSH-1 flowsheet aqueous feed composition component flowrates, the kerosene and $\mathrm{O}_{2}$ flowrates, and the fluidizing air flowrate were entered into the input file (based on liters of feed per hour). By iteration with the Gibbs energy minimization equilibrium output results, the less thermodynamically stable solid compounds were pared from the input file; the gas and aqueous "IN" streams portion of this input file is presented in the Appendix, Table 11. The output results for the calcine compounds determined, at the bed mean temperature of $400^{\circ} \mathrm{C}$, is presented in Table 6.

Table 6. Estimate of Calcine Compounds in RSH-1; HSC Equilibrium Calculations.

\begin{tabular}{|c|c|c|c|c|c|c|}
\hline \multicolumn{7}{|l|}{ C:|RSH1R1.OGI } \\
\hline Components & Phase & Units & MW g/mol & $\begin{array}{c}\text { Component } \\
\text { mols } \\
\text { a } 400^{\circ} \mathrm{C} \\
\end{array}$ & $\begin{array}{l}\text { Component } \\
\operatorname{mass}(\mathrm{g} / \mathrm{hr})\end{array}$ & $\begin{array}{c}\text { Component } \\
\text { mass wt } \%\end{array}$ \\
\hline $\mathrm{Al} 2 \mathrm{O} 3(\mathrm{C})$ & 3 & $\mathrm{kmol}$ & 101.961 & $6.13 \mathrm{E}-01$ & $6.247 \mathrm{E}+01$ & $36.926 \%$ \\
\hline $\mathrm{A} 12 \mathrm{O} 3$ & 3 & kmol & 101.961 & $5.56 \mathrm{E}-01$ & $5.668 \mathrm{E}+01$ & $33.505 \%$ \\
\hline $\mathrm{A} 12 \mathrm{O} 3(\mathrm{~K})$ & 3 & kmol & 101.961 & $1.73 \mathrm{E}-01$ & $1.767 \mathrm{E}+01$ & $10.446 \%$ \\
\hline $\mathrm{A} 12 \mathrm{O} 3(\mathrm{D})$ & 3 & kmol & 101.961 & $1.25 \mathrm{E}-01$ & $1.270 \mathrm{E}+01$ & $7.509 \%$ \\
\hline NaNO3 & 3 & kmol & 84.995 & $1.09 \mathrm{E}-01$ & $9.304 \mathrm{E}+00$ & $5.500 \%$ \\
\hline $\mathrm{A} 12 \mathrm{O} 3(\mathrm{G})$ & 3 & kmol & 101.961 & 2.87E-02 & $2.925 \mathrm{E}+00$ & $1.729 \%$ \\
\hline $\mathrm{MgO}^{*} \mathrm{~A} 12 \mathrm{O} 3$ & 3 & kmol & 142.266 & $1.26 \mathrm{E}-02$ & $1.789 \mathrm{E}+00$ & $1.057 \%$ \\
\hline $\mathrm{CaCO} 3$ & 3 & $\mathrm{kmol}$ & 100.089 & $1.18 \mathrm{E}-02$ & $1.184 \mathrm{E}+00$ & $0.700 \%$ \\
\hline $\mathrm{B} 2 \mathrm{O} 3$ & 3 & kmol & 69.618 & $1.19 \mathrm{E}-02$ & $8.294 \mathrm{E}-01$ & $0.490 \%$ \\
\hline B2O3(G) & 3 & kmol & 69.618 & 8.08E-03 & $5.626 \mathrm{E}-01$ & $0.333 \%$ \\
\hline $\mathrm{CaCO} 3(\mathrm{~A})$ & 3 & $\mathrm{kmol}$ & 100.089 & $7.26 \mathrm{E}-03$ & 7.267E-01 & $0.430 \%$ \\
\hline $\mathrm{CaO} * 2 \mathrm{Al} 2 \mathrm{O} 3$ & 3 & $\mathrm{kmol}$ & 260.002 & $3.87 \mathrm{E}-03$ & $1.006 \mathrm{E}+00$ & $0.595 \%$ \\
\hline $\mathrm{NaCl}$ & 2 & kmol & 58.443 & $4.51 \mathrm{E}-03$ & $2.636 \mathrm{E}-01$ & $0.156 \%$ \\
\hline $\mathrm{A} 12 \mathrm{O} 3 * \mathrm{H} 2 \mathrm{O}(\mathrm{B})$ & 3 & $\mathrm{kmol}$ & 119.976 & $1.83 \mathrm{E}-03$ & $2.190 \mathrm{E}-01$ & $0.129 \%$ \\
\hline $\mathrm{Al} 2 \mathrm{O} 3 * \mathrm{SiO} 2(\mathrm{D})$ & 3 & $\mathrm{kmol}$ & 162.046 & $1.74 \mathrm{E}-03$ & $2.820 \mathrm{E}-01$ & $0.167 \%$ \\
\hline $\mathrm{Fe} 2 \mathrm{O} 3$ & 3 & $\mathrm{kmol}$ & 159.692 & $1.25 \mathrm{E}-03$ & $1.996 \mathrm{E}-01$ & $0.118 \%$ \\
\hline $\mathrm{A} 12 \mathrm{O} 3 * \mathrm{H} 2 \mathrm{O}$ & 3 & kmol & 119.976 & $7.08 \mathrm{E}-04$ & 8.497E-02 & $0.050 \%$ \\
\hline $\mathrm{HgO}$ & 3 & kmol & 216.589 & $6.21 \mathrm{E}-04$ & $1.344 \mathrm{E}-01$ & $0.079 \%$ \\
\hline $\mathrm{MgO}$ & 3 & $\mathrm{kmol}$ & 40.304 & 4.14E-04 & $1.668 \mathrm{E}-02$ & $0.010 \%$ \\
\hline $\mathrm{MgO}(\mathrm{M})$ & 3 & kmol & 40.304 & $2.73 \mathrm{E}-04$ & $1.102 \mathrm{E}-02$ & $0.007 \%$ \\
\hline $\mathrm{Al} 2 \mathrm{O} 3 * \mathrm{SrO}$ & 3 & $\mathrm{kmol}$ & 205.581 & $2.10 \mathrm{E}-04$ & $4.317 \mathrm{E}-02$ & $0.026 \%$ \\
\hline $\mathrm{HgO}(\mathrm{Y})$ & 3 & $\mathrm{kmol}$ & 216.589 & $1.07 \mathrm{E}-04$ & 2.309E-02 & $0.014 \%$ \\
\hline $\mathrm{Eu} 2 \mathrm{O} 3$ & 3 & $\mathrm{kmol}$ & 351.918 & $5.87 \mathrm{E}-05$ & $2.065 \mathrm{E}-02$ & $0.012 \%$ \\
\hline $\mathrm{CaO} * \mathrm{~A} 12 \mathrm{O} 3$ & 3 & $\mathrm{kmol}$ & 158.041 & $3.53 \mathrm{E}-05$ & $5.575 \mathrm{E}-03$ & $0.003 \%$ \\
\hline Eu2O3(M) & 3 & kmol & 351.918 & 4.13E-05 & $1.455 \mathrm{E}-02$ & $0.009 \%$ \\
\hline $\mathrm{MgO} 2$ & 3 & $\mathrm{kmol}$ & 56.304 & $3.60 \mathrm{E}-05$ & $2.027 \mathrm{E}-03$ & $0.001 \%$ \\
\hline \multirow[t]{2}{*}{$\mathrm{MgCO} 3$} & 3 & $\mathrm{kmol}$ & 84.314 & $2.04 \mathrm{E}-06$ & $1.722 \mathrm{E}-04$ & $0.000 \%$ \\
\hline & & & \multicolumn{2}{|c|}{ Total calcine $\operatorname{mass}(\mathrm{g} / \mathrm{hr})=$} & 169.17 & $100.00 \%$ \\
\hline
\end{tabular}

Keep in mind these results are only an estimate. Calcination is not an equilibrium process and the rates of compound formation are unknown ${ }^{8}$. Although a mean bed temperature is 
assumed, bed material undergoes a cyclic sequence of cooling and heating during its migration in the fluidized bed circulation pattern; where this cycle starts is arbitrary. Cooling occurs as material passes through the feed spray and is coated. Drying further cools the particle while some denitration/mineralization occurs. Drying, and then denitration/mineralization rates are accelerated when the material is heated due to the kerosene combustion; the material is ready for another cycle. This ideal cycle is the calcination period; the temperature amplitude during this period affects compound formation and crystal growth. Historically, XRD data has indicated that most of the calcine compounds are amorphous ${ }^{6,9}$. Transmission Electron Microscopy (TEM) technology is required to determine the scale of crystals in calcine.

The $\mathrm{wt} \%$ of elements in this estimate of compounds in the RSH-1 was calculated; this result is presented in the Appendix, Table 12. The redundant compounds in Table 6 were combined (alumina most notably); this shorter compound list is presented in Table 13.

The element $\mathrm{wt} \%$ results from this estimate made with HSC software are compared with the fusion and microprobe results in Table 7 . These results were reasonably acceptable. The carbon result was interesting; the microprobe detected $0.12 \mathrm{wt} \%$ and the HSC estimated $0.14 \mathrm{wt} \%$ (due to $1.1 \mathrm{wt} \% \mathrm{CaCO}_{3}$ estimated in the $\mathrm{RSH}-1$ ). Twenty-six wt $\%$ carbon was detected in a sample of fluorinel/sodium (Run17) pilot plant calcine via an X-Ray Physical Electron Spectroscopy method (XPS) ${ }^{6}$. Brewer and Kessinger concluded however that their result may have been due to surface contamination. The microprobe carbon results obtained here for RSH-1 are believed to be accurate. This carbon is part of calcine matrix, formed during the calcination process; it is not due to surface/atmospheric contamination ${ }^{10}$. Furthermore, it was concluded that the carbon is from the kerosene (as estimated by the HSC results).

Table 7. Compare HSC Estimated Element wt\% Against Fusion/Microprobe Results.

\begin{tabular}{|c|c|c|c|c|c|c|}
\hline Method & \multicolumn{5}{|c|}{ Analyte } & O \\
\hline $\begin{array}{c}\text { Estimate } \\
\text { from HSC } \\
\text { Calcs }\end{array}$ & 48.49 & 1.55 & 0.54 & 0.26 & 47.6 & 0.14 \\
\hline $\begin{array}{c}\text { Fusion } \\
\text { wt\% }\end{array}$ & 45.54 & 1.94 & 0.35 & 0.32 & - & - \\
\hline $\begin{array}{c}\text { Microprob } \\
\text { avg. wt \% }\end{array}$ & 44.1 & 0.92 & 0.50 & 0.52 & 42.48 & 0.12 \\
\hline
\end{tabular}

Utilizing this HSC software estimate of compounds in the RSH-1, the mass conversion was back-calculated for the equilibrium/solubility inhibition liquid phase analytical data and compared with the actual mass conversion data (see $\S 4.2 .5$ ). This exercise was undertaken to validate using this technique for the kinetics testing with actual calcine at the INTEC Remote Analytical Laboratory (RAL). Performing these \% mass dissolution kinetics tests remotely with actual calcine is virtually impossible - and would require significant amounts of calcine. 


\subsection{Baseline Dissolution Kinetics Testing Results}

\subsubsection{Calcine Consumption Coefficient Testing}

The calcine acid consumption coefficient (b) was determined for RSH-1 bed product material. The test matrix results are presented in Table 8. An average value of $\mathbf{b}=19.8$ grams RSH-1 dissolved per mol of acid consumed was obtained.

Table 8. RSH-1 Calcine Acid Consumption Coefficient Testing Results.

\begin{tabular}{|c|c|c|c|c|c|c|}
\hline Testing & Run Description & $\begin{array}{l}\text { starting } \\
\text { g calcine }\end{array}$ & $\begin{array}{l}\text { g calcine } \\
\text { dissolve } \\
d\end{array}$ & Conversion mass & $\begin{array}{c}\mathrm{molH}^{+} \\
\text {consumed }\end{array}$ & $\begin{array}{l}\text { b } \\
\text { g calcine dissolved } \\
/ \text { mol H }{ }^{+} \text {consumed }\end{array}$ \\
\hline \multirow{4}{*}{$\begin{array}{c}\text { RSH-1 } \\
\text { Bed Product }\end{array}$} & $2 \mathrm{~g} / 100 \mathrm{mil}$ of $4 \mathrm{M}$ acid $@ 60^{\circ} \mathrm{C}$ for $60 \mathrm{~min}$ & 1.8559 & 1.2663 & 0.682 & $7.00 \mathrm{E}-02$ & 18.1 \\
\hline & $2 \mathrm{~g} / 100 \mathrm{ml}$ of $4 \mathrm{M}$ acid $@>95^{\circ} \mathrm{C}$ for $60 \mathrm{~min}$. & 1.771 & 1.4058 & 0.794 & $6.16 \mathrm{E}-02$ & 22.8 \\
\hline & $2 \mathrm{~g} / 100 \mathrm{ml}$ of $6 \underline{\bar{M}}$ acid $@>95^{\circ} \mathrm{C}$ for $60 \mathrm{~min}$. & 1.7949 & 1.4072 & 0.784 & $7.22 \mathrm{E}-02$ & 19.5 \\
\hline & $2 \mathrm{~g} / 100 \mathrm{ml}$ of $6 \mathrm{M}$ acid@ $>95^{\circ} \mathrm{C}$ for $7 \mathrm{hrs}$. & 1.7952 & 1.6456 & 0.917 & $8.71 \mathrm{E}-02$ & 18.9 \\
\hline
\end{tabular}

\subsubsection{Order of Reaction Testing Results}

The data from the order of reaction testing are presented in the Appendix, Table 14. The order of reaction was determined for the incipient rate of dissolution at time zero. To determine this, the mass dissolution data at the 1,2,3,6, and 12 minute dissolution times was plotted versus time. This plot was curve-fit with a $3^{\text {rd }}$ order non-uniform rational B-spline algorithm; this algorithm provides a smooth non-oscillating first derivative back to the origin. The first derivative of this function at time zero was the initial rate of dissolution $-d X /\left.d t\right|_{@ t=z e r o}$.

Results for the $0.5 \underline{\mathrm{M}}$ data is presented in the Appendix, Figure 11. Curve-fitting results for this testing is presented in the Appendix, Table 15.

An initial dissolution rate was determined for each of the acid concentrations. If a plot of the $\ln \{$ rate form $\}$ versus $\ln \left[\mathrm{H}^{+}\right]$yields a straight-line fit, then that rate form describes the initial dissolution rate, and the slope of the line is the order of reaction based on the acid

concentration $^{11}$. For the heterogeneous rate form $-\frac{m_{0}}{S_{0}} \frac{d X}{d t}\left[\frac{g \text { dissolved }}{\mathrm{cm}^{2} \text { min }}\right]$ was used, where $\mathrm{S}_{0} / \mathrm{m}_{0}$ is the initial surface area per gram of calcine. This was assumed a constant value over all the acid concentrations because the riffled same-size bed particle material was used throughout this testing. For the homogeneous rate form $-\frac{m_{0}}{V} \frac{d X}{d t}\left[\frac{g \text { dissolved }}{\mathrm{cm}^{3} \min }\right]$ was used, where $\mathrm{V}$ is the dissolution volume at a given acid concentration. The $\ln \{$ rate form $\}$ versus $\ln \left[\mathrm{H}^{+}\right]$for these two rate forms is shown in Figure 4. 


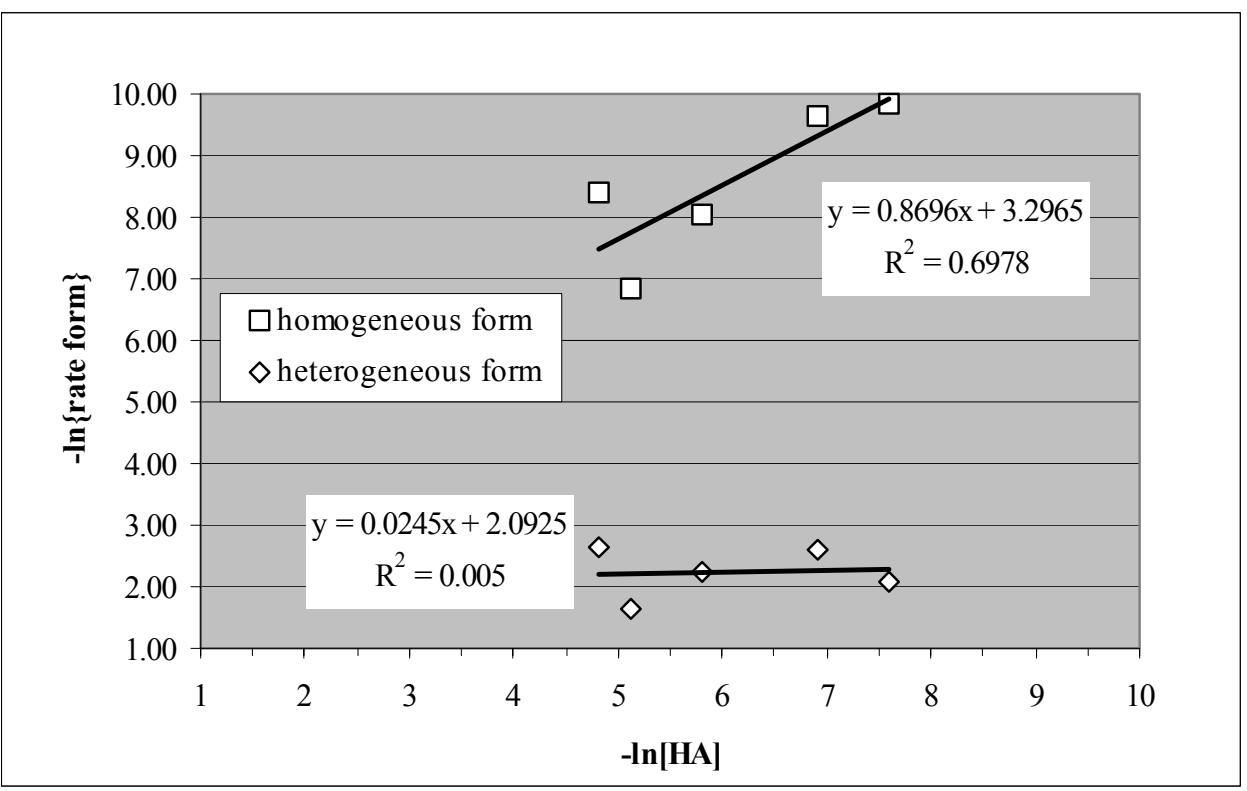

Figure 4. Order of Reaction Analysis; $\ln \{$ rate form $\}$ versus $\ln \left[\mathrm{H}^{+}\right]$

These results were marginally satisfactory. As was observed for the Run74 zirconia pilot plant calcine testing, the homogeneous rate form fit the data better than the heterogeneous rate form $^{4}$. The previous Run 74 testing was done with milled bed material, and that the testing done here with RSH-1 was with intact bed particles. These poor fit results were believed due to polydisperse dissolution - where the "parent" bed particle breaks apart into smaller particles as the dissolution progresses (as was observed for the Run74 testing). 
An interesting result was observed when the RSH-1 alumina pilot plant calcine initial dissolution rate data was combined with the Run74 zirconia pilot plant calcine data to generate a plot of $\ln \left\{d X /\left.d t\right|_{\left.\right|_{0}}\right\}$ versus $\ln \left\{\right.$ dia. $\left._{0}\right\}$. This combined data is presented in Table 9, and plotted in Figure 5.

Table 9. RSH-1 and Run 74 Combined Rate Data.

\begin{tabular}{|c|c|c|c|c|}
\hline Material & $\begin{array}{c}d_{0} \\
(\mu \mathrm{m})\end{array}$ & $\ln \left\{\mathbf{d}_{\mathbf{0}}\right\}$ & $\mathbf{d X} / \mathbf{d t}_{0}$ & $\ln \left\{\mathbf{d X} / \mathbf{d t}_{\mathbf{0}}\right\}$ \\
\hline \multirow{4}{*}{$\begin{array}{l}\text { Milled } \\
\text { Run74 }\end{array}$} & 58 & 4.06 & 0.384 & -0.957 \\
\hline & 69 & 4.23 & 0.333 & -1.100 \\
\hline & 90 & 4.50 & 0.274 & -1.295 \\
\hline & 116 & 4.75 & 0.252 & -1.378 \\
\hline \multirow{2}{*}{ Milled RSH-1 } & 137 & 4.92 & 0.223 & -1.501 \\
\hline & 275 & 5.62 & 0.176 & -1.737 \\
\hline $\begin{array}{c}\text { Run74 } \\
\text { Bed Particle }\end{array}$ & 462 & 6.14 & 0.198 & -1.619 \\
\hline \multirow{3}{*}{ RSH-1 Bed Particle } & 475 & 6.16 & 0.192 & -1.650 \\
\hline & 655 & 6.48 & 0.108 & -2.226 \\
\hline & 925 & 6.83 & 0.0487 & -3.022 \\
\hline
\end{tabular}

From this plot, a characteristic dissolution fractal dimension, $\mathrm{D}_{\mathrm{R}}$, (as described in Ref. 12) was determined for milled pilot plant calcine material, and for bed particle material. A $D_{R}$ of 2.51 was obtained for the milled calcine. Ulrich, et al ${ }^{13}$ interpret $2.0 \leq \mathrm{D}_{\mathrm{R}} \leq 3.0$ to be in the regime of diffusion dissolution of non-Brownian particles. A $D_{R}$ of 0.99 was obtained for the bed particle dissolution data; this was interpreted as dissolution of Smoluchowskian particles (particles for which the ratio of the particle radius to the electric double layer thickness is large ${ }^{14}$ ). It is pointed out that $D_{R}$, in addition to describing the dissolution process mechanism, "carries physically meaningful information about the growth process" (of the calcine bed particles). Continued review of dissolution phenomena in light of this fractal interpretation may provide some important and useful understanding of calcine structural characteristics, and of the calcine dissolution phenomena. The result from this fractal treatment of the dissolution data further supports the indication that calcine dissolution is more dependent upon its physical characteristics, rather than its chemical characteristics. 


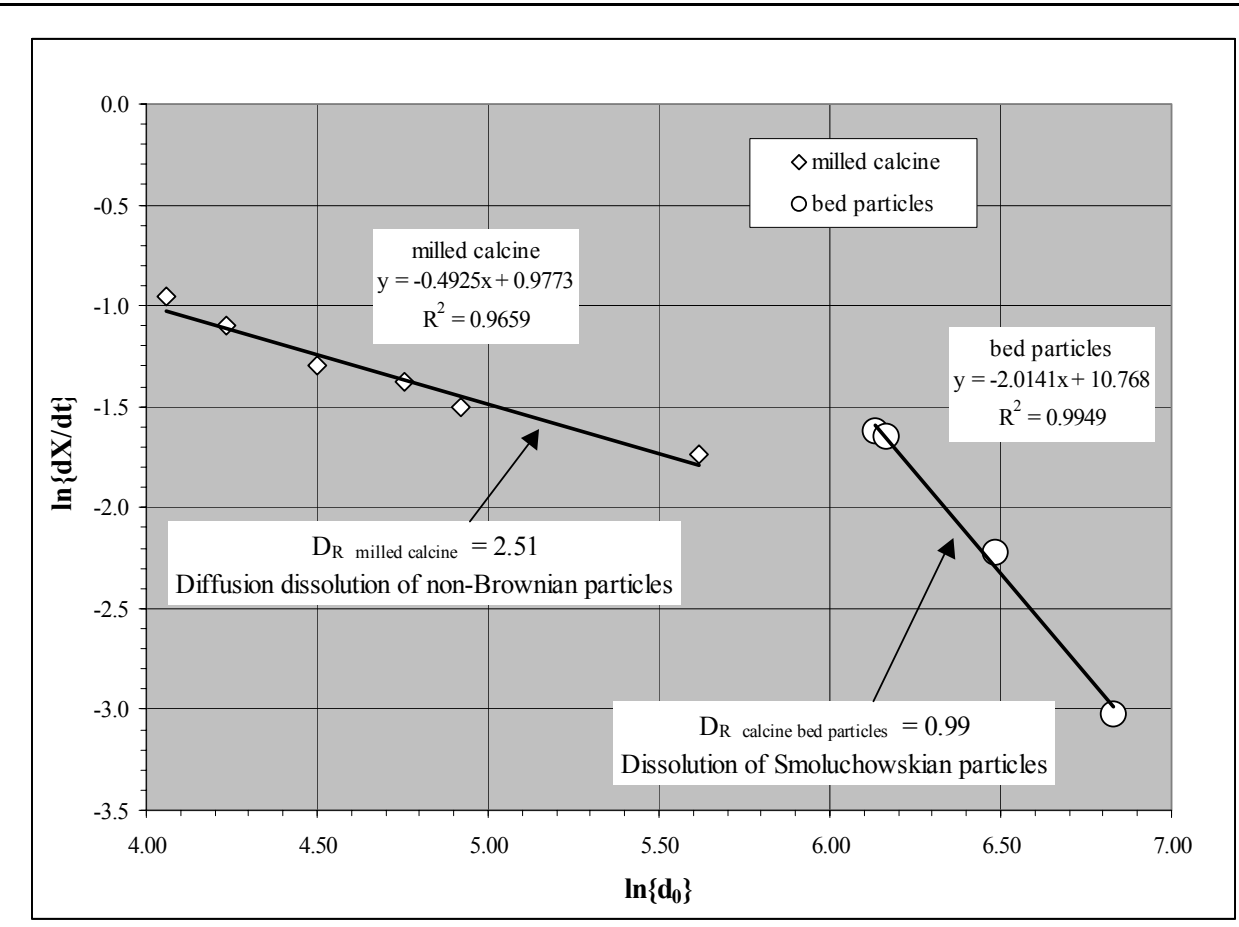

Figure 5. Fractal dimension interpretation of calcine dissolution.

\subsubsection{Arrhenius Analysis Testing Results}

Initial dissolution rates were determined from curvefit of the Arrhenius testing 1, 2, 3, 6, and 12 minute mass dissolution data at the respective temperatures. Mass conversion data and curvefit results are presented in Table 16 and Table 17. A plot of $\ln \{$ rate $\}$ versus $1 / T$ is presented in Figure 6. The slope of this line is $\mathrm{E}_{\mathrm{A}} / \mathrm{R}$ (see Ref. 11). From this plot, an apparent activation energy $\left(\mathrm{E}_{\mathrm{A}}\right)$ of $26.9 \mathrm{kcal} / \mathrm{mol}$ was determined for $\mathrm{RSH}-1$ alumina pilot plant calcine under conditions of $6 \underline{\mathrm{M}}$ unchanging acid concentration. This result was satisfactorily in line with typical values of 10 -to-30 kcal/mol for mineral dissolution ${ }^{15}$. 


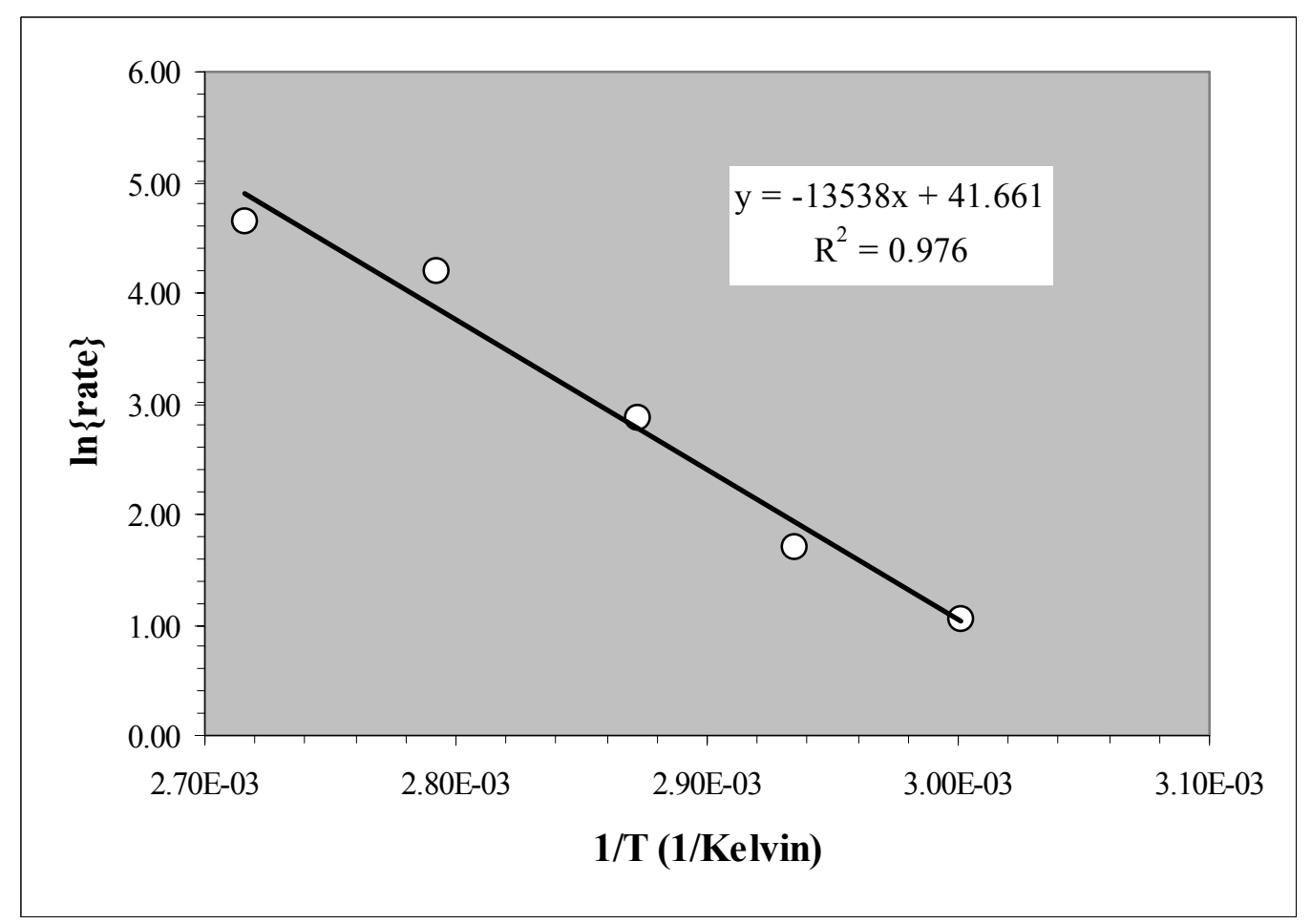

Figure 6. Arrhenius analysis plot

\subsubsection{Dissolution Rate Controlling Mechanism Testing Results}

The dissolution rate controlling determination testing was completed. The dissolution data results for this testing is presented in the Appendix, Table 18. These data were curvefit to determine the time required to achieve a given mass conversion. At the given mass conversion, the time and the corresponding particle size were paired; these results are presented in the Appendix, Table 19. A plot of $\ln \left\{\right.$ time $\left._{\Theta x}\right\}$ versus $\ln \left\{\right.$ dia. $\left._{0}\right\}$ was generated to determine the dissolution rate controlling mechanism. If the slope is unity, dissolution is reaction rate controlled; if the slope is 1.5 to 2-dissolution is film mass transfer controlled; and if the slope is 2 , then dissolution is internal diffusion controlled ${ }^{11}$. This plot is shown in Figure 7. 


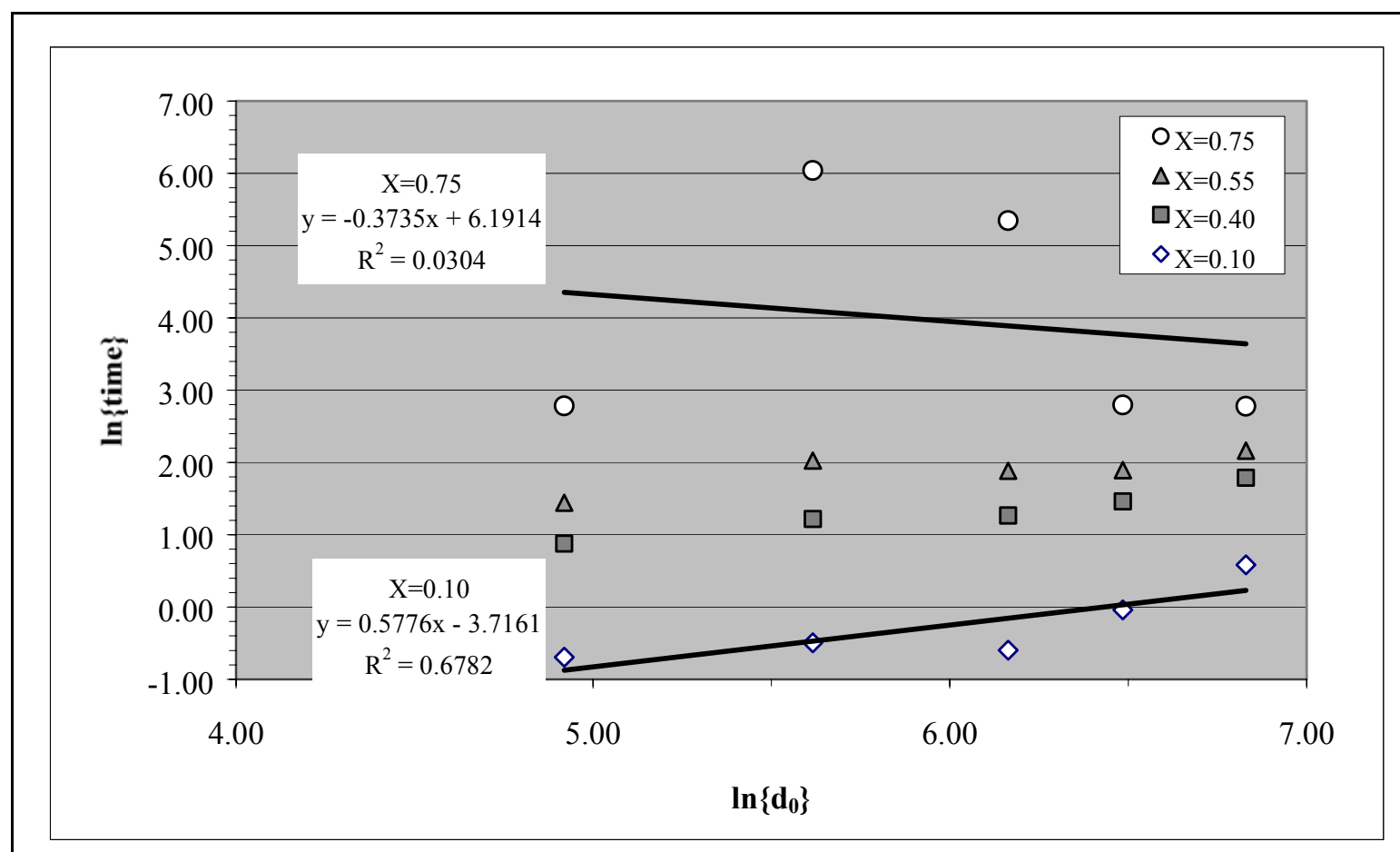

Figure 7. Rate controlling determination; $\ln \{$ time $\}$ vs. $\ln \left\{\mathrm{d}_{0}\right\}$.

These results are marginal. The scatter in the data, especially at the higher conversion, was believed to be a result of dissolution in a polydisperse regime (as noted in the order of reaction results section). In the kinetics work done with the Run74 zirconia pilot plant calcine, rate controlling testing was performed exclusively with milled bed material; a more satisfactory fit was observed for that data. Nevertheless, it was noted that, just as with all previous calcine dissolution testing, this testing with $\mathrm{RSH}-1$ showed the familiar initial rapid dissolution then the leveling-out of the rate, and the non-attainment of $100 \%$ dissolution after long dissolution times_-indicating the characteristics of internal mass diffusion controlled dissolution.

\subsubsection{Equilibrium/Solubility Inhibition Testing Results}

The liquid phase analytical analyses results for the 1,2,3,6, and 12 minute Arrhenius testing were combined with analyses results from the 1 and 6 hour tests $\left(75^{\circ} \mathrm{C}\right.$ data). These analytical analysis results are presented in the Appendix, Table 20. Component conversion was calculated based on the liquid phase concentration data and the fusion analyses results; these results are presented in Table 21 and Table 22. The plot of component conversion versus time is presented in Figure 8. If component liquid phase concentrations increased at first, but then decreased at longer times, then solubility inhibition of complete dissolution is indicated. This was not the case observed for these RSH-1 testing results (see Figure 8). It was concluded that, because aluminum comprised the majority of the calcine $\mathrm{wt} \%$, the slowing dissolution rate of alumina compounds was preventing complete dissolution - the data does not suggest that complete dissolution of RSH-1 calcine is equilibrium/solubility inhibited. 


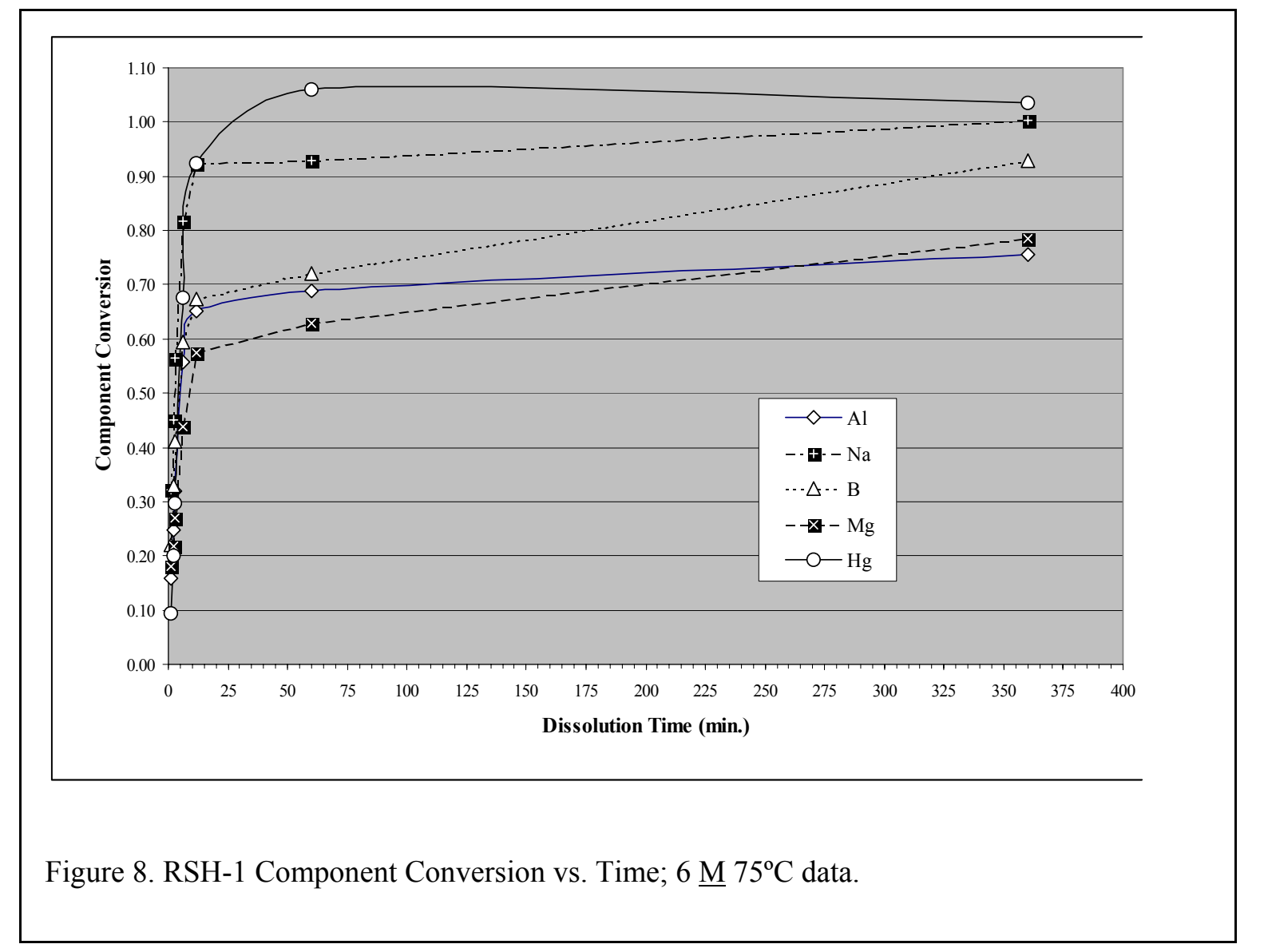

Mass conversion was back-calculated from these liquid phase component conversion results and the HSC software estimated wt\% of compounds in the RSH-1 (the combined compound wt\%'s were used; Table 12). These results are compared with the experimentally obtained mass conversions in Table 10. Overall, this technique is reasonably accurate for estimating \% mass dissolution from liquid phase analytical chemistry data. It is recommended estimating mass conversion for dissolution testing with actual calcine at the RAL. The greatest relative difference was noted for times less than 5 minutes into the dissolution. This caused a $10 \%$ error in the evaluation of $d X /\left.d t\right|_{@ t=z e r o}$; the value from the experimental mass dissolution data was 0.192 versus a value of 0.172 derived for the HSC estimated \% mass dissolution. 
Table 10. Comparison of Mass Conversion; Experimental vs. Back-Calculated.

\begin{tabular}{cccc}
$\begin{array}{c}\text { Time } \\
(\min )\end{array}$ & Exp X & Calc X & \% diff \\
\hline \hline 1 & 0.192 & 0.172 & $11.1 \%$ \\
2 & 0.279 & 0.263 & $5.9 \%$ \\
3 & 0.38 & 0.338 & $11.2 \%$ \\
6 & 0.552 & 0.575 & $-4.1 \%$ \\
12 & 0.683 & 0.673 & $1.5 \%$ \\
60 & 0.713 & 0.707 & $0.8 \%$ \\
360 & 0.789 & 0.779 & $1.2 \%$
\end{tabular}

The greatest percent mass dissolution observed during this testing with RSH-1 was $93.0 \%$ (see Table 16). This was achieved after eight hours of dissolution at $95^{\circ} \mathrm{C}$. 


\section{CONCLUSIONS AND RECOMMENDATIONS}

The conclusions and recommendations based on the results of this work follow:

1. Chemical and physical analyses were performed on the RSH-1 alumina type pilot plant calcine bed material. Elemental fusion analysis results agree well with microprobe analysis results. Results of thermodynamic modeling to estimate the chemical compounds in RSH-1 were reasonably acceptable when compared with the fusion and microprobe results. Triplicate fusion analysis and additional microprobe analyses, although these are resource taxing, are recommended if better accuracy is necessary.

2. Baseline dissolution kinetics testing was completed:

- The calcine acid consumption coefficient was determined for RSH-1 bed product material. An average value of $\mathbf{b}=19.8$ grams RSH-1 dissolved per mol of acid consumed was obtained.

- Order of reaction testing indicated that the homogeneous rate form fit the rate data better than the heterogeneous rate form. This was also observed for previous dissolution kinetics work done with zirconia-type pilot plant calcine. A characteristic dissolution fractal dimension, $\mathrm{D}_{\mathrm{R}}$, was determined for alumina and zirconia pilot plant calcine milled material and bed particles. The result from this fractal treatment of the dissolution data further supports the indication that calcine dissolution is more dependent upon its physical characteristics, rather than its chemical characteristics.

- Arrhenius testing yielded an apparent activation energy $\left(\mathrm{E}_{\mathrm{A}}\right)$ of $26.9 \mathrm{kcal} / \mathrm{mol}$ for RSH-1 alumina pilot plant calcine under conditions of constant $6 \underline{\mathrm{M}}$ acid concentration. This result is comparable to typical values for mineral dissolution.

- The results from the dissolution rate controlling mechanism tests were inconclusive; data scatter was attributed to polydisperse dissolution of the bed particles. Nevertheless, as was observed in the previous zirconia pilot plant calcine dissolution kinetics work, there was the familiar initial rapid dissolution, then the leveling-out of the rate, and the non-attainment of $100 \%$ dissolution after long dissolution times. The RSH-1 dissolution kinetics also had the characteristics of internal mass diffusion controlled dissolution.

- The equilibrium/solubility inhibition testing results indicated that the slowing dissolution rate of alumina compounds was preventing complete dissolution. The data does not suggest that complete dissolution of RSH-1 calcine is equilibrium/solubility inhibited. The greatest percent mass dissolution observed during this testing with RSH-1 was $93.0 \%$; this was achieved after eight hours of dissolution at $95^{\circ} \mathrm{C}$. 
3. In conjunction with the compound estimates from the thermodynamic modeling, mass conversion was back-calculated from liquid phase compound conversion results. This technique is reasonably accurate for estimating the mass conversion from liquid phase analytical chemistry data. This exercise was undertaken to validate using this technique for the kinetics testing with actual calcine at the INTEC Remote Analytical Laboratory. Performing these \% mass dissolution kinetics tests remotely with actual calcine is virtually impossible — and would require a significant amount of radioactive calcine. Utilization of this technique is recommended for estimating mass conversion for kinetics testing with actual calcine in the future. Triplicate fusion analysis on actual calcine to be used in kinetics testing is recommended. 


\section{REFERENCES}

1. U. S. Department of Energy, "Idaho High-Level Waste and Facilities Disposition Draft Environmental; Impact Statement”, DOE/EIS-0287D, December 1999.

2. B. J. Newby, "Dissolution and Disintegration of Calcine Clinkers", EINCO Internal Letter Report NBY-15-79 to K. F. Childs, November 1979.

3. K. N. Brewer, "Dissolution Scoping Tests on Two and Three-Way Blend Calcine", WINCO Internal Letter Report KNB-2-91 to B. H. O’Brien, March 19991.

4. T. A. Batcheller, "Dissolution Kinetics of Zirconia Calcine”, INEEL/EXT-99-00566, June 1999.

5. R. S. Herbst, Idaho National Engineering and Environmental Laboratory, personal communication.

6. K. N. Brewer, G. F. Kessinger, L. L. Littleton, A. L. Olson, "Physical and Chemical Characteristics of Fluorinel/Sodium Calcine Generated during $30 \mathrm{~cm}$ Pilot-plant Run17”, WINCO-1139, July 1993.

7. Roine, Outokumpu HSC Chemistry ${ }^{\circledR}$ for Windows, Chemical Reaction and Equilibrium Software with Extensive Thermochemical Database, Version 4.1, Outokumpu Research Oy Information Service, PO Box 60, FIN-28101 Pori, Finland; available from ESM Software, 2235 Wade Court, Hamilton, Ohio 45013.

8. B. H. O'Brien, "Estimation of Alkali Metal Mole Percent and Weight of Calcined Solids for ICPP Calcine”, INEL-95/0184, March 1995.

9. J. R. Berreth, "Inventories and Properties of ICPP Calcined High-Level Waste", WINCO-1050, February 1988.

10. K. E. Wright, Idaho National Engineering and Environmental Laboratory, personal communication.

11. O. Levenspiel, Chemical Reaction Engineering, John Wiley \& Sons, 1972.

12. D. Avnir, Fractal Approach to Heterogeneous Chemistry, John Wiley \& Sons Ltd., 1992.

13. M. Momonaga, J. Stavek, J. Ulrich, "Interpretation of Dissolution Rates by the Reaction Fractal Dimension”, Journal of Crystal Growth, 166, 1053 (1996).

14. D. J. Shaw, Introduction to Colloid and Surface Chemistry, Butterworth \& Co. Ltd., 1980.

15. F. Habashi, Principals of Extractive Metallurgy, Gordon and Breach, New York, 1969. 


\section{APPENDIX}

\section{Test Results Data}




\section{Microprobe Analyses of RSH-1 Calcine}

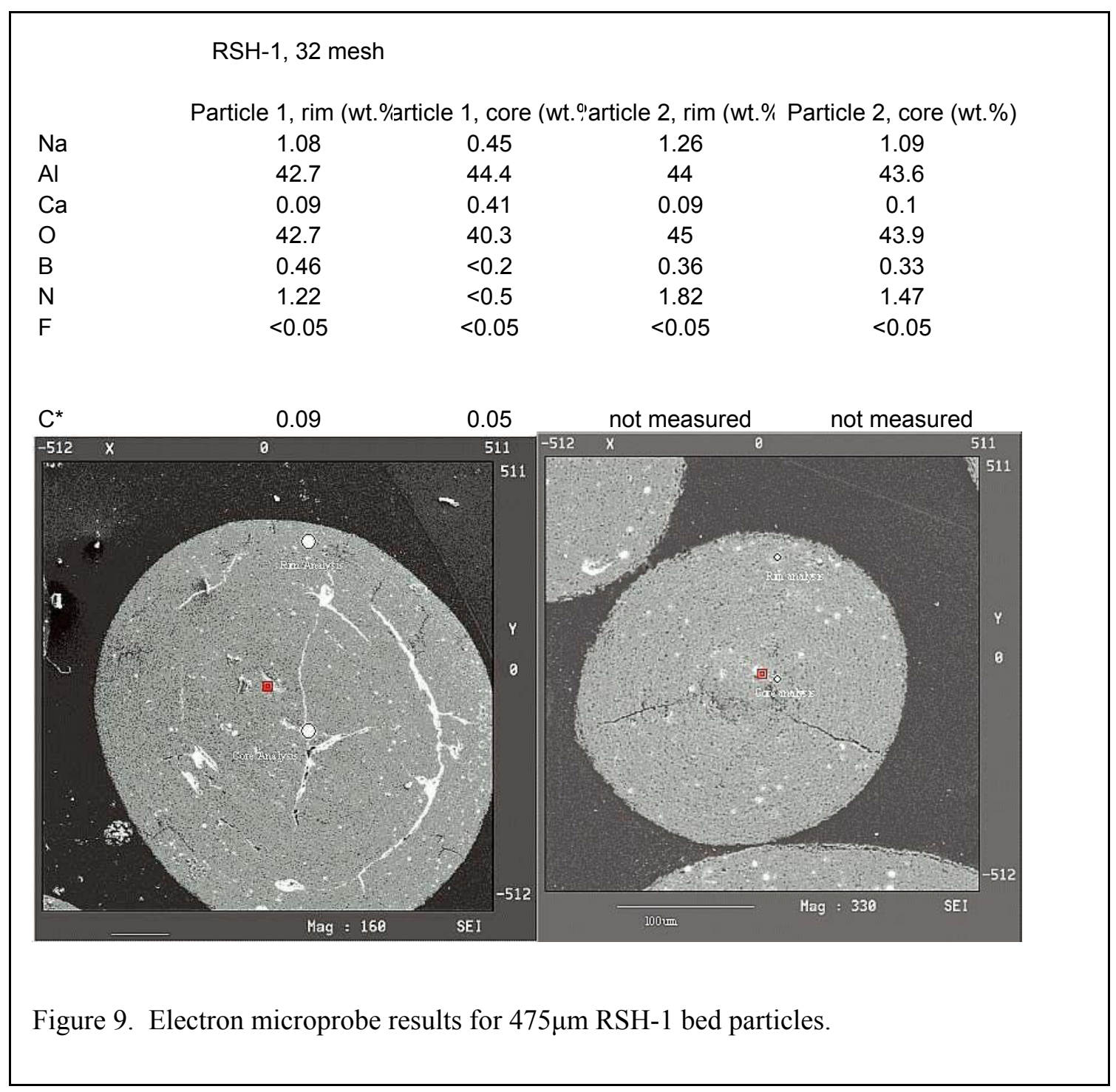




\section{Microprobe Analyses of RSH-1 Calcine}

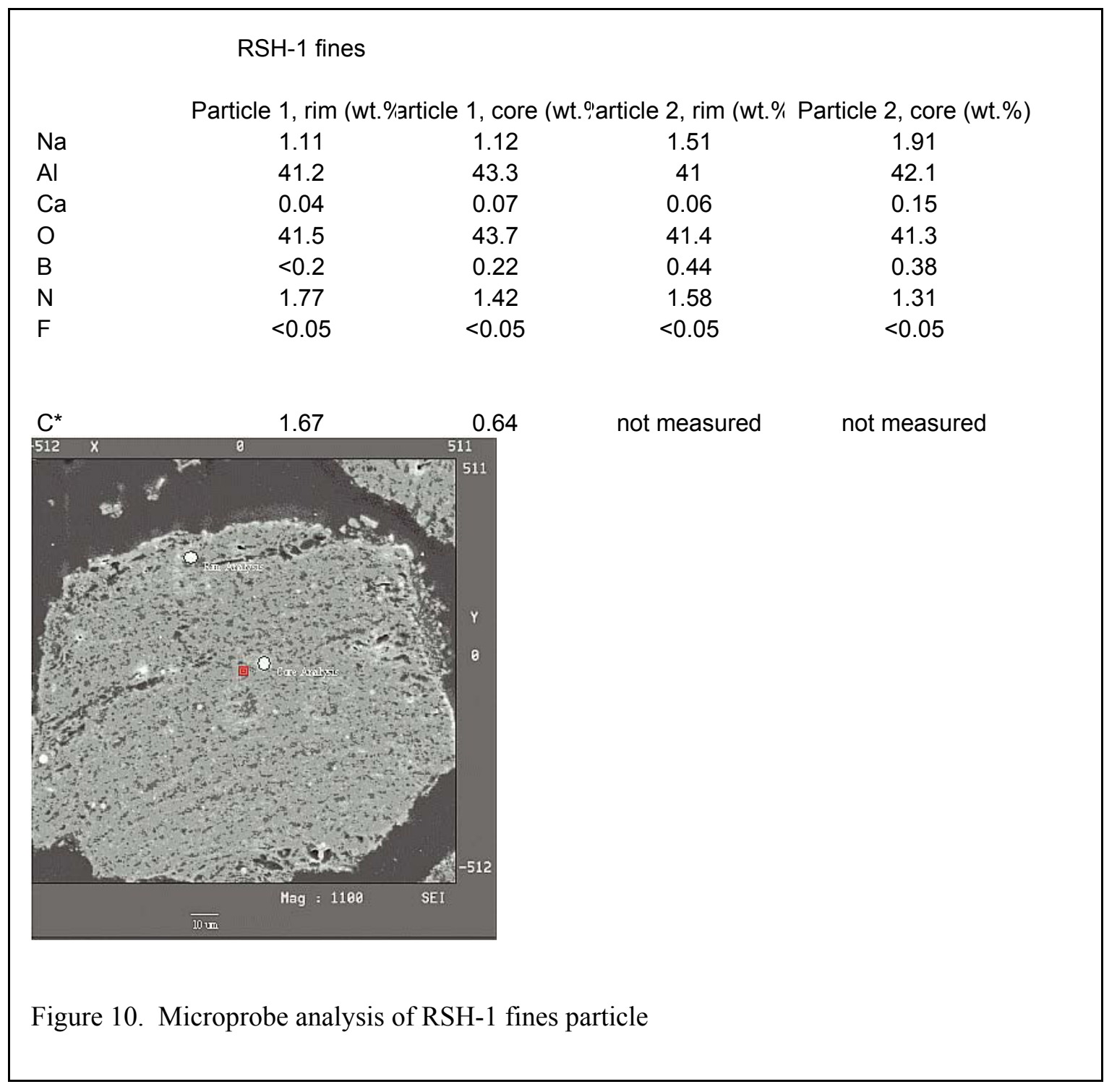




\section{HSC Chemistry Input File for RSH-1 Calcine}

Table 11. HSC Input File

\begin{tabular}{|c|c|c|c|c|}
\hline & A & $\mathrm{B}$ & $\mathrm{C}$ & $\mathrm{D}$ \\
\hline 1 & $\begin{array}{l}\text { SPECIES } \\
\text { Formula }\end{array}$ & Temp ${ }^{0} \mathrm{C}$ & $\mathrm{mols} / \mathrm{hr}$ & $\mathrm{mol} \%$ \\
\hline 2 & Gases & & 217.680 & 100.000 \\
\hline 3 & $\mathrm{CO}(\mathrm{g})$ & 25.000 & & \\
\hline 4 & $\mathrm{CO} 2(\mathrm{~g})$ & 25.000 & & \\
\hline 5 & $\mathrm{Cl} 2(\mathrm{~g})$ & 25.000 & & \\
\hline 6 & $\mathrm{H} 2 \mathrm{O}(\mathrm{g})$ & 25.000 & & \\
\hline 7 & $\mathrm{Hg}(\mathrm{g})$ & 25.000 & & \\
\hline 8 & $\mathrm{HgCl} 2(\mathrm{~g})$ & 25.000 & & \\
\hline 9 & $\mathrm{~N} 2(\mathrm{~g})$ & 25.000 & 127.400 & 58.526 \\
\hline 10 & $\mathrm{NO}(\mathrm{g})$ & 25.000 & & \\
\hline 11 & $\mathrm{NO} 3(\mathrm{~g})$ & 25.000 & & \\
\hline 12 & $\mathrm{NO} 2(\mathrm{~g})$ & 25.000 & & \\
\hline 13 & $\mathrm{O} 2(\mathrm{~g})$ & 25.000 & 87.900 & 40.380 \\
\hline 14 & $\mathrm{C} 12 \mathrm{H} 26(\mathrm{DODg})$ & 25.000 & 2.380 & 1.093 \\
\hline 15 & Aqueous & & 116.054 & 100.000 \\
\hline 16 & $\mathrm{H} 2 \mathrm{O}$ & 25.000 & 100.000 & 86.167 \\
\hline 17 & $\mathrm{Al}(+3 \mathrm{a})$ & 25.000 & 3.040 & 2.619 \\
\hline 18 & $\mathrm{Al}(\mathrm{NO} 3) 3(\mathrm{a})$ & 25.000 & & \\
\hline 19 & BH4(-a) & 25.000 & & \\
\hline 20 & $\mathrm{BO} 2(-\mathrm{a})$ & 25.000 & 0.040 & 0.034 \\
\hline 21 & $\mathrm{CO} 2(\mathrm{a})$ & 25.000 & & \\
\hline 22 & $\mathrm{Ca}(+2 \mathrm{a})$ & 25.000 & 0.023 & 0.020 \\
\hline 23 & $\mathrm{CaCO} 3(\mathrm{a})$ & 25.000 & & \\
\hline 24 & $\mathrm{Cl} 2(\mathrm{a})$ & 25.000 & & \\
\hline 25 & $\mathrm{Cl}(-\mathrm{a})$ & 25.000 & 0.005 & 0.004 \\
\hline 26 & $\mathrm{Cs}(+\mathrm{a})$ & 25.000 & 0.000 & 0.000 \\
\hline 27 & $\mathrm{CsCl}(\mathrm{a})$ & 25.000 & & \\
\hline 28 & $\mathrm{Eu}(+4 \mathrm{a})$ & 25.000 & & \\
\hline 29 & $\mathrm{Eu}(+3 \mathrm{a})$ & 25.000 & 0.000 & 0.000 \\
\hline 30 & $\mathrm{Eu}(+2 a)$ & 25.000 & & \\
\hline 31 & $\mathrm{Fe}(+3 \mathrm{a})$ & 25.000 & 0.003 & 0.002 \\
\hline 32 & $\mathrm{Fe}(+2 \mathrm{a})$ & 25.000 & & \\
\hline 33 & $\mathrm{H}(+\mathrm{a})$ & 25.000 & 1.588 & 1.368 \\
\hline 34 & HNO2(a) & 25.000 & & \\
\hline 35 & HNO3(a) & 25.000 & & \\
\hline 36 & $\mathrm{Hg}(\mathrm{a})$ & 25.000 & & \\
\hline 37 & $\mathrm{Hg}(+2 \mathrm{a})$ & 25.000 & 0.024 & 0.021 \\
\hline 38 & $\operatorname{Mg}(+2 a)$ & 25.000 & 0.013 & 0.011 \\
\hline 39 & $\mathrm{~N} 2(\mathrm{a})$ & 25.000 & & \\
\hline 40 & $\mathrm{NO} 2(-\mathrm{a})$ & 25.000 & & \\
\hline 41 & NO3(-a) & 25.000 & 11.054 & 9.525 \\
\hline 42 & $\mathrm{NH} 4(+\mathrm{a})$ & 25.000 & 0.148 & 0.127 \\
\hline 43 & $\mathrm{Na}(+\mathrm{a})$ & 25.000 & 0.114 & 0.098 \\
\hline 44 & $\mathrm{NaCO} 3(-\mathrm{a})$ & 25.000 & & \\
\hline 45 & $\mathrm{O} 2(\mathrm{a})$ & 25.000 & & \\
\hline 46 & $O(-a)$ & 25.000 & & \\
\hline 47 & $\mathrm{O} 2(-\mathrm{a})$ & 25.000 & & \\
\hline 48 & $02(-2 a)$ & 25.000 & & \\
\hline
\end{tabular}




\section{HSC Chemistry Wt\% Elements in RSH-1 Calcine}

Table 12. HSC Wt\% Elements in RSH-1

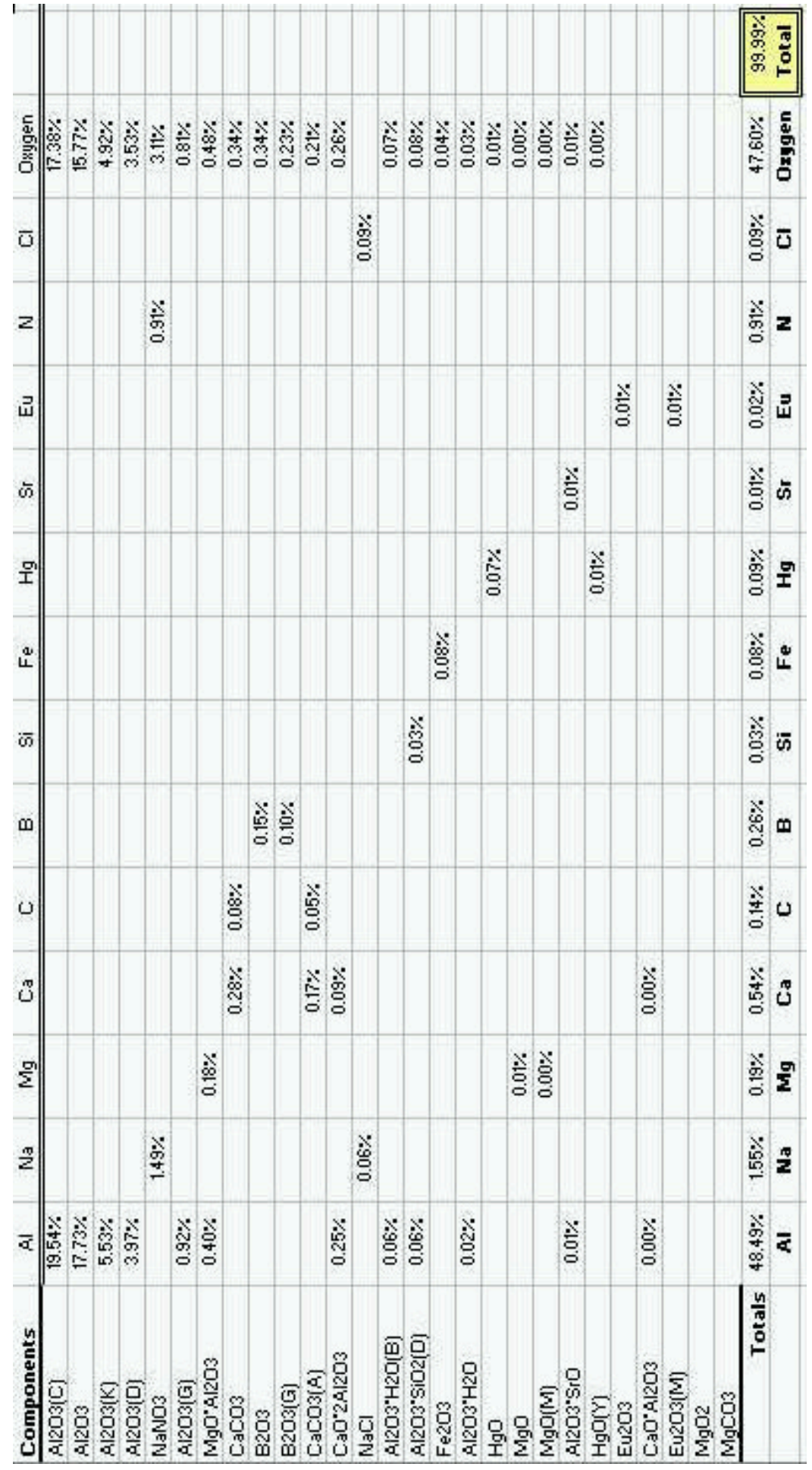


HSC Chemistry Primary Compounds in RSH-1 Calcine

Table 13. HSC Primary Compounds in RSH-1

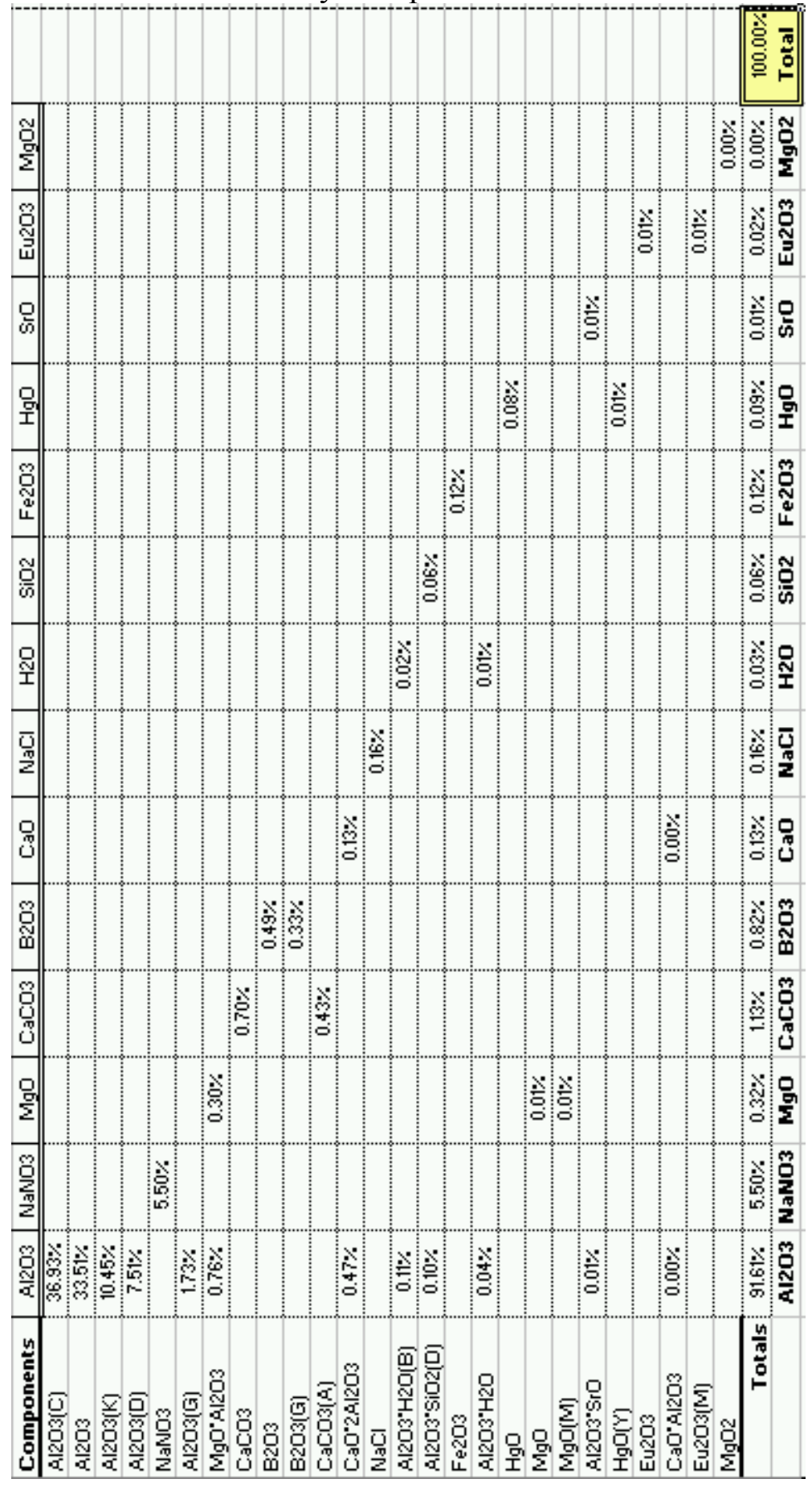




\section{Order of Reaction Testing Data}

Table 14. Order of Reaction Testing Data. 0.5 Molar Data

\begin{tabular}{|c|c|c|c|c|}
\hline $\begin{array}{l}\text { time } \\
(\mathrm{min})\end{array}$ & $\mathrm{x} @ \mathrm{t}$ & $\begin{array}{c}\text { mass } \\
\text { calcine } \\
(\mathrm{g})\end{array}$ & $\begin{array}{c}\text { filter@0 } \\
(\mathrm{g})\end{array}$ & $\begin{array}{c}\text { filter@t } \\
(\mathrm{g})\end{array}$ \\
\hline 0 & 0 & - & - & - \\
\hline 1 & 0.126 & 0.4616 & 73.1518 & 73.5553 \\
\hline 2 & 0.213 & 0.3865 & 71.9304 & 72.2347 \\
\hline 3 & 0.259 & 0.4646 & 73.0726 & 73.4168 \\
\hline 6 & 0.423 & 0.3881 & 72.4535 & 72.6775 \\
\hline 12 & 0.661 & 0.3762 & 73.5171 & 73.6446 \\
\hline
\end{tabular}

1 Molar Data

$\begin{array}{ccccc}0 & 0 & - & - & - \\ 1 & 0.073 & 0.4445 & 73.0183 & 73.4305 \\ 2 & 0.134 & 0.4713 & 72.7395 & 73.1476 \\ 3 & 0.210 & 0.4345 & 72.7614 & 73.1045 \\ 6 & 0.409 & 0.4434 & 72.6325 & 72.8945 \\ 12 & 0.633 & 0.4472 & 72.8575 & 73.0216\end{array}$

3 Molar Data

$\begin{array}{ccccc}0 & 0 & - & - & - \\ 1 & 0.107 & 1.1921 & 73.2254 & 74.2897 \\ 2 & 0.187 & 1.1961 & 72.7234 & 73.6957 \\ 3 & 0.280 & 1.1141 & 73.4635 & 74.2651 \\ 6 & 0.510 & 1.2771 & 73.3800 & 74.0053 \\ 12 & 0.682 & 1.2240 & 71.9127 & 72.3024\end{array}$

6 Molar Data

$\begin{array}{ccccc}0 & 0 & - & - & - \\ 1 & 0.193 & 2.1816 & 72.5125 & 74.2738 \\ 2 & 0.279 & 2.2092 & 72.1593 & 73.7516 \\ 3 & 0.375 & 2.1560 & 72.3538 & 73.7020 \\ 6 & 0.539 & 2.1742 & 72.3054 & 73.3078 \\ 12 & 0.694 & 2.2373 & 72.385 & 73.0691 \\ 60 & 0.713 & 2.2437 & 71.9823 & 72.6269 \\ 360 & 0.789 & 1.0133 & 72.0362 & 72.2500\end{array}$

8 Molar Data

$\begin{array}{ccccc}0 & 0 & - & - & - \\ 1 & 0.072 & 1.2230 & 73.0020 & 74.1373 \\ 2 & 0.143 & 1.2410 & 72.8082 & 73.8719 \\ 3 & 0.232 & 1.2558 & 73.2086 & 74.1734 \\ 6 & 0.431 & 1.2035 & 72.6353 & 73.3195 \\ 12 & 0.638 & 1.2897 & 71.9868 & 72.4541\end{array}$


Determine $d X /\left.d t\right|_{@_{t} t=z e r o}$ for Order of Reaction Testing

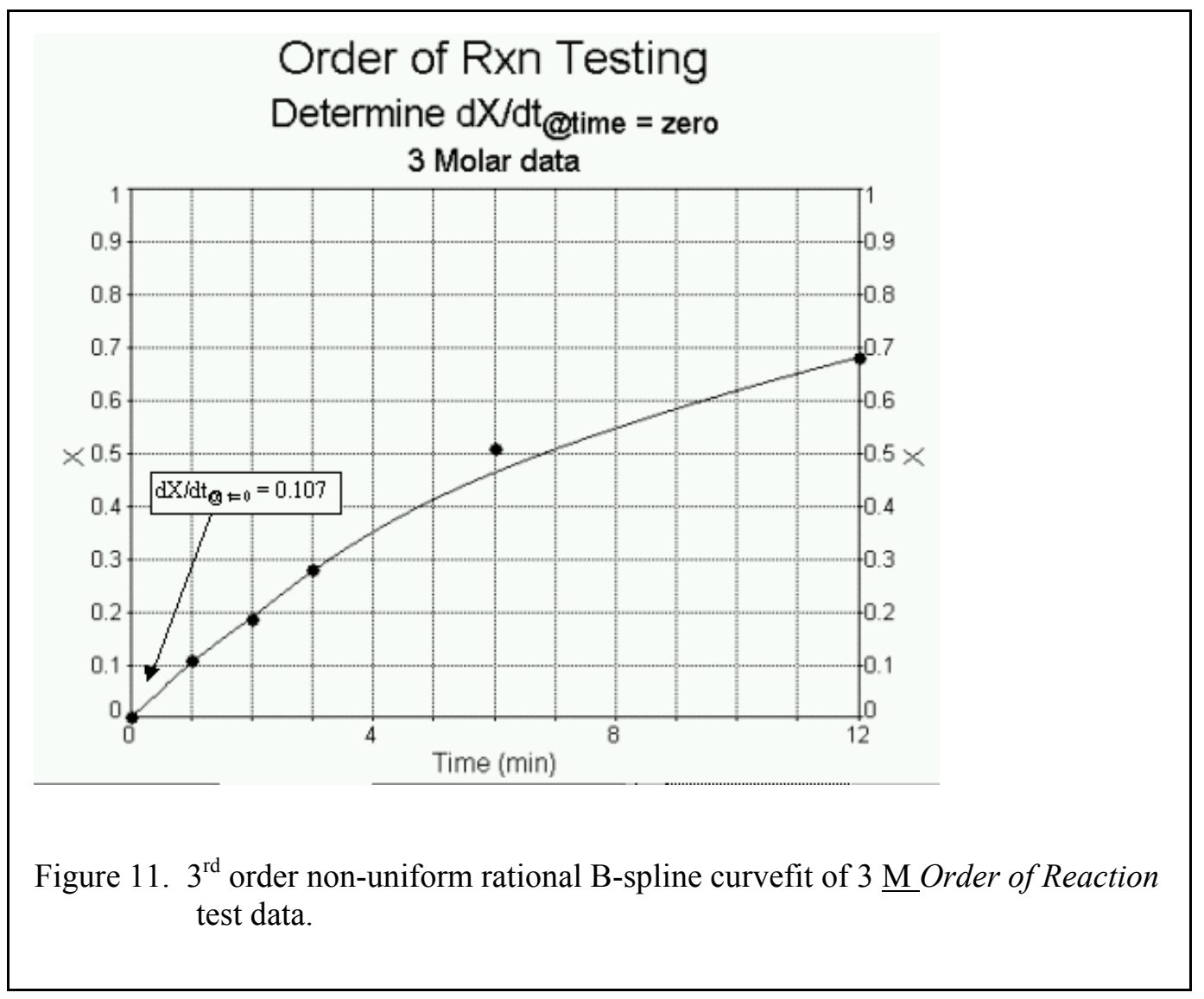

Table 15. Order of Reaction Initial Rate Curve Fit Results and Rate Forms.

\begin{tabular}{|c|c|c|c|c|c|c|c|c|}
\hline Molar & $\begin{array}{c}\text { [acid] } \\
(\mathrm{mol} / \mathrm{ml})\end{array}$ & $-\ln \{$ acid $\}$ & $\mathrm{dX} / \mathrm{dt}$ & $-\ln \{\mathrm{dX} / \mathrm{dt}\}$ & $\begin{array}{c}\mathrm{m}_{0} \\
\text { (gram) }\end{array}$ & $\begin{array}{c}\text { Vol } \\
(\mathrm{mls})\end{array}$ & $\{$ homog form\} & $-\ln \{$ homog form $\}$ \\
\hline 0.5 & 0.0005 & 7.60 & 0.126 & 2.07 & 0.4154 & 1000 & $5.23 \mathrm{E}-05$ & 9.86 \\
\hline 1 & 0.001 & 6.91 & 0.073 & 2.62 & 0.4481 & 500 & $6.54 \mathrm{E}-05$ & 9.63 \\
\hline 3 & 0.003 & 5.81 & 0.107 & 2.23 & 1.2007 & 400 & $3.21 \mathrm{E}-04$ & 8.04 \\
\hline 6 & 0.006 & 5.12 & 0.192 & 1.65 & 2.1916 & 400 & $1.05 \mathrm{E}-03$ & 6.86 \\
\hline 8 & 0.008 & 4.83 & 0.072 & 2.63 & 1.2426 & 400 & $2.24 \mathrm{E}-04$ & 8.41 \\
\hline
\end{tabular}




\section{Arrhenius Testing Data Results}

Table 16. Arrhenius Testing Data Results

\begin{tabular}{|c|c|c|c|c|c|c|c|c|}
\hline \multicolumn{9}{|l|}{ \% Mass Conversion } \\
\hline Temperature $\left({ }^{0} \mathrm{C}\right)$ & 1 & 2 & 3 & 6 & 12 & 60 & 360 & 480 \\
\hline 60.0 & 2.3 & 3.3 & 6.5 & 17.5 & 33.0 & - & - & - \\
\hline 67.5 & 3.8 & 10.1 & 14.7 & 31.5 & - & - & - & - \\
\hline 75.0 & 18.0 & 27.2 & 37.6 & 54.6 & 69.0 & 71.3 & 78.9 & \\
\hline 85.0 & 44.4 & 60.3 & 64.6 & 70.5 & 72.8 & - & - & - \\
\hline 95.0 & 55.3 & 66.0 & 69.4 & 70.6 & 72.3 & 78.9 & - & 93.0 \\
\hline
\end{tabular}

Table 17. Arrhenius Testing Data Curve-fit Results.

\begin{tabular}{cccc} 
& \multicolumn{3}{c}{ Rate } \\
$\mathrm{T}^{0} \mathrm{C}$ & $1 / \mathrm{T}$ & (curve-fit) & $\ln \{$ Rate $\}$ \\
95.0 & $2.72 \mathrm{E}-03$ & 104.70 & 4.651 \\
85.0 & $2.79 \mathrm{E}-03$ & 67.10 & 4.206 \\
75.0 & $2.87 \mathrm{E}-03$ & 17.60 & 2.868 \\
67.5 & $2.94 \mathrm{E}-03$ & 5.50 & 1.705 \\
60.0 & $3.00 \mathrm{E}-03$ & 2.88 & 1.058
\end{tabular}




\section{Dissolution Rate Controlling Mechanism Testing Data}

Table 18. Dissolution Rate Controlling Testing Data.

$\begin{array}{ccccc}\begin{array}{c}125 \text { to } 150 \mu \mathrm{m} \text { data } \\ \text { time } \\ (\mathrm{min})\end{array} & \mathrm{X} @ \mathrm{t} & \begin{array}{c}\text { mass } \\ \text { calcine } \\ (\mathrm{g})\end{array} & \begin{array}{c}\text { filter } @ 00 \\ (\mathrm{~g})\end{array} & \begin{array}{c}\text { filter @ t } \\ (\mathrm{g})\end{array} \\ 0 & 0 & - & - & - \\ 2 & 0.447 & 2.1608 & 72.8585 & 74.0530 \\ 6 & 0.644 & 2.0915 & 72.8426 & 73.5873 \\ 12 & 0.752 & 2.2160 & 73.0045 & 73.5548 \\ 30 & 0.780 & 2.2090 & 73.4074 & 73.8938 \\ 60 & 0.798 & 2.1889 & 72.6953 & 73.1383 \\ 420 & 0.857 & 2.2135 & 72.6834 & 72.9998\end{array}$

250 to $300 \mu \mathrm{m}$ data

$\begin{array}{ccccc}0 & 0 & - & - & - \\ 2 & 0.353 & 2.2457 & 72.1896 & 73.6432 \\ 6 & 0.536 & 2.2184 & 73.1596 & 74.1892 \\ 12 & 0.609 & 2.2013 & 73.345 & 74.2054 \\ 30 & 0.638 & 2.1658 & 72.3573 & 73.1413 \\ 60 & 0.649 & 2.1740 & 72.9271 & 73.6909 \\ 420 & 0.747 & 2.2218 & 73.3942 & 73.9569\end{array}$

355 to $595 \mu \mathrm{m}$ data

$\begin{array}{ccccc}0 & 0 & - & - & - \\ 1 & 0.193 & 2.1816 & 72.5125 & 74.2738 \\ 2 & 0.279 & 2.2092 & 72.1593 & 73.7516 \\ 3 & 0.375 & 2.1560 & 72.3538 & 73.7020 \\ 6 & 0.539 & 2.1742 & 72.3054 & 73.3078 \\ 12 & 0.694 & 2.2373 & 72.385 & 73.0691 \\ 60 & 0.713 & 2.2437 & 71.9823 & 72.6269 \\ 360 & 0.789 & 1.0133 & 72.0362 & 72.2500\end{array}$

600 to $710 \mu \mathrm{m}$ data

$\begin{array}{ccccc}0 & 0 & - & - & - \\ 2 & 0.216 & 2.1138 & 72.9622 & 74.6195 \\ 6 & 0.549 & 2.2418 & 72.0167 & 73.0285 \\ 12 & 0.744 & 2.2694 & 73.2036 & 73.7835 \\ 30 & 0.822 & 2.2985 & 73.3774 & 73.7875 \\ 60 & 0.830 & 2.1368 & 72.293 & 72.6570 \\ 420 & 0.873 & 2.1367 & 72.7645 & 73.0351\end{array}$

850 to $1000 \mu \mathrm{m}$ data

$\begin{array}{ccccc}0 & 0 & - & - & - \\ 2 & 0.097 & 2.2753 & 73.2819 & 75.3359 \\ 6 & 0.421 & 2.2158 & 73.1315 & 74.4140 \\ 12 & 0.730 & 2.1438 & 71.9145 & 72.4930 \\ 30 & 0.909 & 2.1744 & 73.3122 & 73.5109 \\ 60 & 0.915 & 2.2211 & 73.2449 & 73.4340 \\ 420 & 0.935 & 2.1946 & 71.6587 & 71.8023\end{array}$




\section{Dissolution Rate Controlling Mechanism Testing Data Curve-fit Results}

Table 19. Dissolution Rate Controlling Mechanism Data Curve-fit Results.

\begin{tabular}{cccr}
\multicolumn{4}{c}{$X=0.10$} \\
dnot $(\mu \mathrm{m})$ & time $@ X$ & $\ln \{$ dnot $\}$ & $\ln \{$ time $\}$ \\
137 & 0.50 & 4.92 & -0.69 \\
275 & 0.61 & 5.62 & -0.49 \\
475 & 0.55 & 6.16 & -0.60 \\
655 & 0.96 & 6.48 & -0.04 \\
925 & 1.79 & 6.83 & 0.58 \\
\multicolumn{4}{c}{$\mathrm{X}=0.40$} \\
137 & 2.40 & 4.92 & 0.88 \\
275 & 3.37 & 5.62 & 1.21 \\
475 & 3.54 & 6.16 & 1.26 \\
655 & 4.31 & 6.48 & 1.46 \\
925 & 5.98 & 6.83 & 1.79 \\
\multicolumn{4}{c}{$\mathrm{X}=0.55$} \\
137 & 4.23 & 4.92 & 1.44 \\
275 & 7.58 & 5.62 & 2.03 \\
475 & 6.59 & 6.16 & 1.89 \\
655 & 6.65 & 6.48 & 1.89 \\
925 & 8.72 & 6.83 & 2.17 \\
4 & $\mathrm{C}=0.75$ & \\
137 & 16.20 & 4.92 & 2.79 \\
275 & 420.00 & 5.62 & 6.04 \\
475 & 210.00 & 6.16 & 5.35 \\
655 & 16.36 & 6.48 & 2.79 \\
925 & 16.12 & 6.83 & 2.78
\end{tabular}




\section{Equilibrium/Solubility Inhibition Testing Liquid Phase Analytical Results}

Table 20. Equilibrium/Solubility Inhibition Testing Liquid Phase Analytical Results.

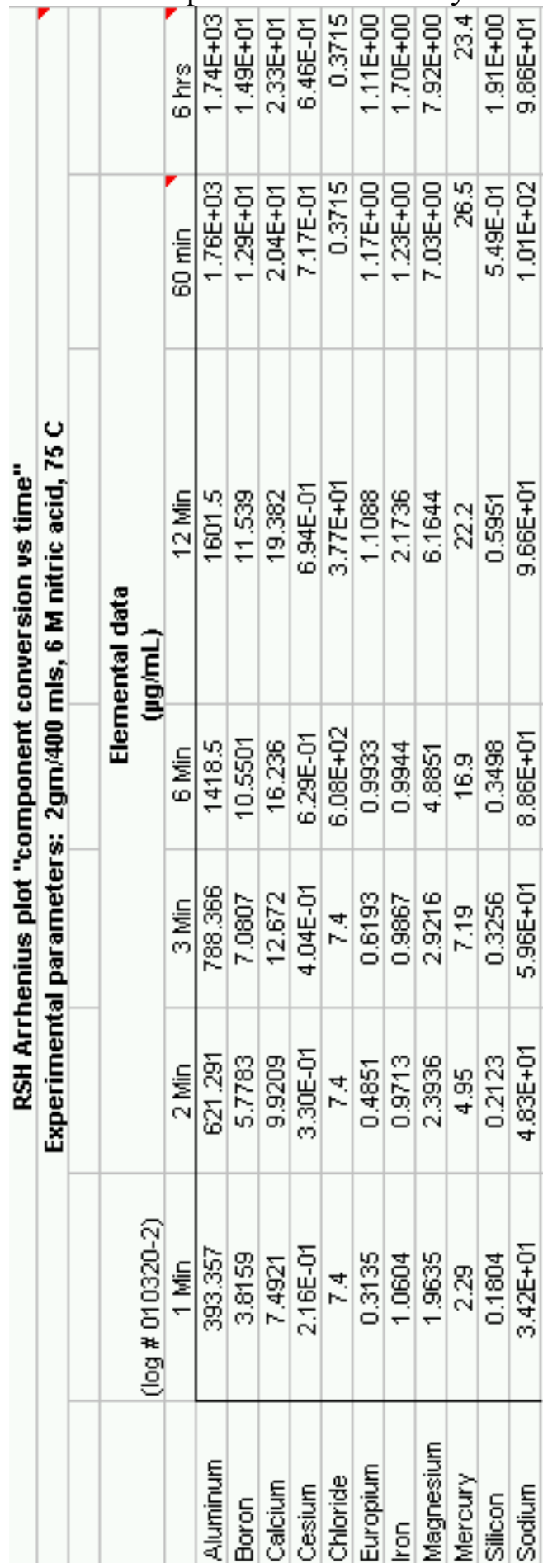




\section{Equilibrium/Solubility Inhibition Testing Elemental Conversion Results}

Table 21. Equilibrium/Solubility Inhibition Testing Elemental Conversion Results.

Data from 1st set of dissolutions

\begin{tabular}{|c|c|c|c|c|c|}
\hline Starting Mass(gms) & Volume (mLs) & $\mathrm{Al}_{\text {Initial }}$ & $\mathrm{Al}_{\text {Final }}$ & Conversion $\left(\mathrm{Al}_{\text {Final }} / \mathrm{Al}_{\mid \text {|nitial }}\right)$ & Time (minutes) \\
\hline 2.1816 & 400 & 0.9936 & 0.1573 & 0.1584 & 1 \\
\hline 2.2092 & 400 & 1.0062 & 0.2485 & 0.2470 & 2 \\
\hline 2.1742 & 400 & 0.9902 & 0.3153 & 0.3185 & 3 \\
\hline 2.2373 & 400 & 1.0190 & 0.5674 & 0.5568 & 6 \\
\hline 2.1560 & 400 & 0.9820 & 0.6406 & 0.6524 & 12 \\
\hline 2.2437 & 400 & 1.0219 & 0.7044 & 0.6893 & 60 \\
\hline 1.0133 & 200 & 0.4615 & 0.3489 & 0.7560 & 360 \\
\hline Starting Mass(gms) & Volume (mLs) & $\mathrm{B}_{\text {Initial }}$ & $\mathrm{B}_{\text {final }}$ & Conversion $\left(\mathrm{B}_{\text {Final }} / \mathrm{B}_{\text {Initial }}\right)$ & Time (minutes) \\
\hline 2.1816 & 400 & 0.0069 & 0.0015 & 0.2204 & 1 \\
\hline 2.2092 & 400 & 0.0070 & 0.0023 & 0.3296 & 2 \\
\hline 2.1742 & 400 & 0.0069 & 0.0028 & 0.4104 & 3 \\
\hline 2.2373 & 400 & 0.0071 & 0.0042 & 0.5942 & 6 \\
\hline 2.1560 & 400 & 0.0068 & 0.0046 & 0.6744 & 12 \\
\hline 2.2437 & 400 & 0.0071 & 0.0051 & 0.7222 & 60 \\
\hline 1.0133 & 200 & 0.0032 & 0.0030 & 0.9294 & 360 \\
\hline Starting Mass(gms) & Volume (mLs) & $\mathrm{Ca}_{\text {Initial }}$ & $\mathrm{Ca}_{\text {Final }}$ (avg.) & Conversion $\left(\mathrm{Ca}_{\text {Final }} / \mathrm{Ca}_{\text {|nitial }}\right)$ & Time (minutes) \\
\hline 2.1816 & 400 & 0.0076 & 0.0030 & 0.3967 & 1 \\
\hline 2.2092 & 400 & 0.0076 & 0.0040 & 0.5188 & 2 \\
\hline 2.1742 & 400 & 0.0075 & 0.0051 & 0.6733 & 3 \\
\hline 2.2373 & 400 & 0.0077 & 0.0065 & 0.8383 & 6 \\
\hline 2.1560 & 400 & 0.0075 & 0.0078 & 1.0385 & 12 \\
\hline 2.2437 & 400 & 0.0078 & 0.0082 & 1.0511 & 60 \\
\hline 1.0133 & 200 & 0.0035 & 0.0047 & 1.3273 & 360 \\
\hline Starting Mass(gms) & Volume (mLs) & $\mathrm{Cs}_{\text {Initial }}$ & $\mathrm{Cs}_{\text {Final }}$ & Conversion $\left(\mathrm{Cs}_{\text {Final }} / \mathrm{Cs}_{\text {|nitial }}\right)$ & Time (minutes) \\
\hline 2.1816 & 400 & 0.0004 & 0.0001 & 0.2371 & 1 \\
\hline 2.2092 & 400 & 0.0004 & 0.0001 & 0.3578 & 2 \\
\hline 2.1742 & 400 & 0.0004 & 0.0002 & 0.4451 & 3 \\
\hline 2.2373 & 400 & 0.0004 & 0.0003 & 0.6734 & 6 \\
\hline 2.1560 & 400 & 0.0004 & 0.0003 & 0.7710 & 12 \\
\hline 2.2437 & 400 & 0.0004 & 0.0003 & 0.7654 & 60 \\
\hline 1.0133 & 200 & 0.0002 & 0.0001 & 0.7635 & 360 \\
\hline \multirow{8}{*}{$\begin{array}{c}\text { Starting Mass(gms) } \\
2.1816 \\
2.2092 \\
2.1742\end{array}$} & Volume (mLs) & $\mathrm{Cl}_{\text {Initial }}$ & $\mathrm{Cl}_{\text {Final }}$ & Conversion $\left(\mathrm{Cl}_{\text {Final }} / \mathrm{Cl}_{\text {|nitial }}\right)$ & Time (minutes) \\
\hline & 400 & 0.0954 & 0.0030 & 0.0310 & 1 \\
\hline & 400 & 0.0966 & 0.0030 & 0.0307 & 2 \\
\hline & 400 & 0.0950 & 0.0030 & 0.0311 & 3 \\
\hline & 400 & 0.0978 & 0.2432 & 2.4868 & 6 \\
\hline & 400 & 0.0942 & 0.0151 & 0.1600 & 12 \\
\hline & 400 & 0.0981 & 0.0001 & 0.0015 & 60 \\
\hline & 200 & 0.0443 & 0.0001 & 0.0017 & 360 \\
\hline
\end{tabular}




\section{Equilibrium/Solubility Inhibition Testing Component Conversion Results (cont.)}

Table 22. Equilibrium/Solubility Inhibition Testing Elemental Conversion Results (cont.).

$\begin{array}{ccc} & \text { Starting Mass(gms) } & \text { Volume }(\mathrm{mLs}) \\ & 2.1816 & 400 \\ \mathrm{~m} & 2.2092 & 400 \\ \mathrm{c} & 2.1742 & 400 \\ \text { 흔. } & 2.2373 & 400 \\ & 2.1560 & 400 \\ \mathrm{3} & 2.2437 & 400 \\ & 1.0133 & 200\end{array}$

$E u_{\text {Initial }}$
0.0006
0.0006
0.0006
0.0006
0.0006
0.0006
0.0003

$E u_{\text {Final }}$
0.0001
0.0002
0.0002
0.0004
0.0004
0.0005

$\begin{array}{cc}\text { Conversion }\left(E \mathrm{u}_{\text {Final }} / \mathrm{Eu}_{\text {|nitial }}\right) & \text { Time (minutes) } \\ 0.2183 & 1 \\ 0.3336 & 2 \\ 0.4327 & 3 \\ 0.6745 & 6 \\ 0.7813 & 12 \\ 0.7925 & 60 \\ 0.8320 & 360\end{array}$

Starting Mass(gms) Volume (mLs)

$\begin{array}{lll}2.1816 & 400 & 0.0008\end{array}$

$\begin{array}{lll}2.2092 & 400 & 0.0008\end{array}$

$\begin{array}{cll} & 2.2092 & 400 \\ \overline{\mathrm{o}} & 2.1742 & 400 \\ & 2.2373 & 400 \\ 2.1560 & 400 \\ & 2.2437 & 400 \\ 1.0133 & 200\end{array}$

0.0008

0.0008

0.0008

0.0008

0.0004

\begin{tabular}{|c|c|c|}
\hline & Starting Mass(gms) & Volume (mLs) \\
\hline & 2.1816 & 400 \\
\hline & 2.2092 & 400 \\
\hline & 2.1742 & 400 \\
\hline & 2.2373 & 400 \\
\hline & 2.1560 & 400 \\
\hline & 2.2437 & 400 \\
\hline & 1.0133 & 200 \\
\hline
\end{tabular}

Mginitial

0.0043

0.0044

0.0043

0.0045

0.0043

0.0045

0.0020

$\begin{array}{ccc} & \text { Starting Mass(gms) } & \text { Volume }(\mathrm{mLs}) \\ & 2.1816 & 400 \\ \mathbf{3} & 2.2092 & 400 \\ \mathrm{\Phi} & 2.1742 & 400 \\ \stackrel{\mathrm{z}}{\mathrm{z}} & 2.2373 & 400 \\ & 2.1560 & 400 \\ & 2.2437 & 400 \\ & 1.0133 & 200\end{array}$

$\mathrm{Hg}_{\text {Initial }}$

0.0097

0.0099

0.0097

0.0100

0.0096

0.0100

Starting Mass(gms) Volume $(\mathrm{mLs})$

0.0045

\begin{tabular}{|c|c|c|}
\hline & Starting Mass(gms) & Volume $(\mathrm{mLs})$ \\
\hline & 2.1816 & 400 \\
\hline & 2.2092 & 400 \\
\hline \multirow{5}{*}{$\begin{array}{l}\stackrel{\omega}{\bar{\nu}} \\
\overline{\bar{\delta}}\end{array}$} & 2.1742 & 400 \\
\hline & 2.2373 & 400 \\
\hline & 2.1560 & 400 \\
\hline & 2.2437 & 400 \\
\hline & 1.0133 & 200 \\
\hline
\end{tabular}

Si $\mathrm{initial}$

0.0006

0.0006

0.0006

0.0006

0.0006

0.0006

0.0003

Fe Final $_{\text {(avg.) }}$

Conversion $\left(\mathrm{Fe}_{\text {Final }} / \mathrm{Fe}_{\text {Initial }}\right)$

Time (minutes)

0.0004

0.0004

0.0004

0.0004

0.0009

0.0005

0.0003

$\mathrm{Mg}_{\text {Final }}$ (avg.)

0.0008

0.0010

0.0012

0.0020

0.0025

0.0028

0.5208

0.4711

0.4863

0.4762

1.0802

0.5889

0.8979

1
2
3
6
12
60
360

Conversion ( $\left.\mathrm{Mg}_{\text {Final }} / \mathrm{Mg}_{\text {Initial }}\right) \quad$ Time (minutes) 0.1810

0.2179

0.2702

0.4391

0.5750

0.6304

0.7859

1
2
3
6
12
60
360

\section{$\mathrm{Hg}_{\text {Final }}$ (avg.)}

Conversion $\left(\mathrm{Hg}_{\text {Final }} / \mathrm{Hg}_{\text {Initial }}\right)$ 0.0941

0.2010

0.2966

0.6775

0.9235

1.0593

1.0355

Time (minutes)

0.0020

0.0029
0.0068

0.0089

0.0106

0.0047

Si $i_{\text {Final }}($ avg.)

Conversion (Si $\left.\mathrm{i}_{\text {Final }} / \mathrm{Si}_{\mathrm{I}_{\text {nitial }}}\right)$

0.1271

0.1477

0.2302

0.2403

0.4243

0.3761

1.4501

1
2
3
6
12
60
360

Starting Mass(gms) Volume (mLs) $\quad \mathrm{Na}_{\text {Initial }}$

0.0423

2.1816

2.2092

400

400

0.0429

0.0422

0.0434

0.0418

0.0435

2.1560

400

400

400

0.0197

$\mathrm{Na}_{\text {Final }}($ avg.)

Conversion ( $\left.\mathrm{Na}_{\text {Final }} / \mathrm{Na}_{\text {|nitial }}\right)$

0.3232

0.4508

0.0193

0.0238

0.0354

0.0386

0.0404

0.0197

0.5652

0.8165

0.9238

0.9281

1.0031

Time (minutes)

(minutes)
1
2
3
6
12
60
360

Time (minutes)

(minutes)
1
2
3
6
12
60
360

